\title{
The Tail That Wags the Dog: The Problem of Pre- Merit-Decision Interim Fees and Moral Hazard in the National Vaccine Injury Compensation Program
}

\author{
Timothy M. Todd
}

\section{INTRODUCTION}

Consider the following hypothetical: A prospective client walks into a law office and complains of some general pain in her extremities. She tells the lawyer a general medical history, but nothing appears out of the ordinary. Coincidentally, she tells the lawyer that she received a vaccine a few weeks ago - not a new, cutting-edge vaccine, but one that most people receive without thinking twice about it. The lawyer immediately gives her an engagement letter to sign. After the client leaves, the lawyer hands the file off to another attorney in the office. The second lawyer calls all of the client's medical providers from the past few years and begins to compile the client's medical records. Nothing stands out in those either, except of course the notations about the vaccine administration. The file then passes from lawyer to lawyer in the office, with each attorney billing time to "become familiar" with the facts. Noting the references to the vaccine administration in the medical records, the lawyers think that the vaccine possibly could have caused the pain. Thus, the lawyers submit a claim to the federal government's Vaccine Injury Compensation Program on the client's behalf.

After the chain of lawyers in the office talk to every doctor (including outside doctors), read every page in the file, read hundreds of pages of bland medical records, and of course meet to discuss their findings (several times), they come to the (obvious) conclusion that there's no smoking gun or really any other evidence that the vaccine caused the symptoms or injury. The client is not charged a dime. Nevertheless, the law firm submits a claim for all attorneys' fees and costs to the federal government and then withdraws from the representation. Shortly thereafter, the law firm receives a check from the

${ }^{*}$ Assistant Professor of Law, Liberty University School of Law. 
federal government and cashes it. And, just like that, it's on to the next case.

Does this sound too good to be true? Well, think again. Under the current practice of the National Vaccine Injury Compensation Program (VICP), this hypothetical could, in fact, be reality. This situation arises because of two problems in the VICP: (1) the granting of "pre-meritdecision interim fees" and (2) the current "standard" used to grant those fees.

The National Childhood Vaccine Injury Act of 1986 (hereinafter the "Vaccine Act" or the "Act") ${ }^{1}$ created the VICP. The VICP is in place to compensate victims who are injured (or even killed) by vaccines. Funded by excise taxes on various vaccines, ${ }^{2}$ the VICP is a no-fault, mandatory alternative to traditional civil litigation against a vaccine administrator or manufacturer. ${ }^{3}$ Due to its no-fault nature, there are regulations that dictate if certain symptoms arise after a specific time period after the administration of a particular vaccine, the VICP pays "compensation" to the victim. ${ }^{4}$ If, however, a petitioner's claim does not fall within those regulations, he or she can pursue a traditional cause-infact based claim in the VICP. ${ }^{5}$ The United States Court of Federal Claims - in particular, its Office of Special Masters - serves as the finder of fact and holds quasi-judicial proceedings under the VICP. ${ }^{6}$

The VICP pays attorneys' fees and costs if the petition for compensation is successful. ${ }^{7}$ Unique to the VICP, however, is that it often pays attorneys' fees and costs even if the petition is unsuccessful on the merits. ${ }^{8}$ Even more remarkable - and troubling - is that, due to two decisions of the United States Court of Appeals for the Federal Circuit, ${ }^{9}$ attorneys' fees and costs can be paid to attorneys even before a

1. Pub. L. No. 99-660, 100 Stat. 3755 (1986) (codified as amended at 42 U.S.C. $\S \S 300 a a-1$ to $-34(2012))$.

2. See 42 U.S.C. $§ 300 a a-15(i)(2)$ (2012) (noting payments are to be made from the "Vaccine Injury Compensation Trust Fund"); 26 U.S.C. § 9510 (2012) (creating the Vaccine Injury Compensation Trust Fund); 26 U.S.C. $§ 4131$ (2012) (imposing a seventy-five-cent excise tax on any taxable vaccine)

3. See, e.g., 42 U.S.C. § 300aa-11(a)(2) (2012).

4. These are known as "table injuries." See infra Part II.B (discussing table injuries).

5. The VICP and its operation are discussed in more detail infra at Part II.B.

6. 42 U.S.C. $\$ 300 a a-12(2012)$.

7. Id. $\S 300 \mathrm{aa}-15(\mathrm{e})(1)$.

8. Id. (flush language)

9. Shaw v. Sec'y of Health \& Human Servs., 609 F.3d 1372 (Fed. Cir. 2010); Avera v. Sec'y of Health \& Human Servs., 515 F.3d 1343 (Fed. Cir. 2008); see also infra Part III.D (discussing the effect of these cases on the VICP). 
decision is made on the case's merits, that is, "pre-merit-decision interim fees." 10 Many cases have even allowed the payment of attorneys' fees to a withdrawing attorney before the merit decision. ${ }^{11}$

The practice of awarding pre-merit-decision interim fees is hugely problematic for the VICP. It is contrary to a fair reading of the Vaccine Act, cuts against the historical operation of the VICP, and is contrary to congressional intent. It also creates a remarkable moral hazard problem: neither the petitioner nor the petitioner's lawyer has any incentive to police litigation costs because the taxpayer is paying those costs-win or lose. The moral hazard problem, moreover, has other unintended consequences - for example, a clogging of the Court of Federal Claims' docket. There is even evidence that increased vaccine litigation is affecting the Federal Circuit's docket, too. ${ }^{12}$ Furthermore, because the VICP is funded by excise taxes, any moral hazard problem that leads to an unnecessary payment of funds may lead to increased vaccine costs for the public (as those taxes may need to be increased), which could have unforeseen public health consequences in the long run.

This Article therefore argues that the current practice of awarding pre-merit-decision interim fees must stop. Using bedrock principles and canons of statutory interpretation, this Article demonstrates why a fair reading of the Vaccine Act requires a merit decision before any payment of funds can be made from the VICP. Part II discusses the history of vaccine litigation in the United States, explores the Vaccine Act, and provides an overview of how the VICP operates. Part III demonstrates the problem of pre-merit-decision interim fees, discusses how it arose by two decisions of the Federal Circuit, and explains how those two decisions have greatly affected the VICP today. Finally, Part IV shows how - the current practice notwithstanding-bedrock principles and

\footnotetext{
10. See, e.g., Shaw, 609 F.3d at 1378.

11. See, e.g., D. Golmakani v. Sec'y of Health \& Human Servs., No. 11-577V, 2013 WL 4009664 (Fed. Cl. Spec. Mstr. July 7, 2013); Toor v. Sec'y of Health \& Human Servs., No. 10650V, 2013 WL 4011097 (Fed. Cl. Spec. Mstr. July 3, 2013); Allen v. Sec'y of Health \& Human Servs., No. 11-051V, 2013 WL 3185256 (Fed. Cl. Spec. Mstr. May 30, 2013); Wright v. Sec'y of Health \& Human Servs., No. 10-222V, 2013 WL 1800373 (Fed. Cl. Spec. Mstr. Apr. 4, 2013); Jakes v. Sec'y of Health \& Human Servs., No. 06-831V, 2013 WL 1150518 (Fed. Cl. Spec. Mstr. Feb. 19, 2013); Hiland v. Sec'y of Health \& Human Servs., No. 10-491V, 2012 WL 542683 (Fed. Cl. Spec. Mstr. Jan. 31, 2012); Woods v. Sec'y of Health \& Human Servs., No. 10-377V, 2011 WL 6957598 (Fed. Cl. Spec. Mstr. Dec. 16, 2011).

12. See Brandon L. Boxler, Fixing the Vaccine Act's Structural Moral Hazard, 12 PEPP. DisP. RESOL. L.J. 1, 35 (2012) (noting that petitioners file appeals, petitions for rehearing, and petitions for rehearing en banc at a rate that far surpasses the government because the fees are eventually paid by
} the taxpayer). 
canons of statutory interpretation preclude any pre-merit-decision payment of attorneys' fees and costs from the VICP.

\section{HISTORY OF VACCINE LITIGATION AND THE VACCINE INJURY COMPENSATION PROGRAM}

\section{A. Common Law Vaccine Litigation in the United States}

\section{Vaccine Litigation Before the Vaccine Injury Compensation Program}

Undoubtedly, vaccination against life-threatening and debilitating illnesses is one of the crowning achievements in the history of public health. $^{13}$ Consequently, all fifty states have compulsory vaccination laws. ${ }^{14}$ Ordinarily, compliance with these laws is a prerequisite for school enrollment. ${ }^{15}$ Some estimates indicate that 57,000 children are

13. See, e.g., H.R. REP. No. 99-908, at 5 (1986), reprinted in 1986 U.S.C.C.A.N. 6344, 6345 ("Vaccination of children against deadly, disabling, but preventable infectious diseases has been one of the most spectacularly effective public health initiatives this country has ever undertaken."); see also Erica A. Little, Note, The Role of Special Masters in Off-Table Vaccination Compensation Cases: Assuring Flexibility over Certainty, 16 FED. CIR. B.J. 355, 355 (2007) (stating "[m]any trumpet childhood immunization as one of the most successful public health efforts in the United States"). For example, polio is nearly eliminated from the Western Hemisphere due to massvaccination protocols. See Lisa J. Steel, National Childhood Vaccine Injury Compensation Program: Is This the Best We Can Do for Our Children?, 63 GEO. WASH. L. REV. 144, 149 (1994). Interestingly, there exists evidence of "vaccination" protocols as early as the first millennium. See Stephen P. Calandrillo, Vanishing Vaccinations: Why Are So Many Americans Opting Out of Vaccinating Their Children?, 37 U. Mich. J.L. REFORM 353, 363-64 (2004); James G. Hodge, Jr. \& Lawrence O. Gostin, School Vaccination Requirements: Historical, Social, and Legal Perspectives, 90 KY. L.J. 831, 837 (2002). For example, in India - even prior to 1000 A.D._-patients would be exposed intentionally to smallpox to create immunity. Calandrillo, supra, at 364 (citing Donald A. Henderson \& Bernard Moss, Smallpox and Vaccinia, in VACCINES 74 (Stanley A. Plotkin \& Walter A. Orenstein eds., 3d ed. 1999)).

14. Boxler, supra note 12, at 4-5; see, e.g., CAL. EdUC. CODE § 48216 (West 2006); CAL. Health \& SAFETy Code $\S 120325$ (West 2012); D.C. Code $\S 38-502$ (2001); Md. Code AnN. EDUC. $\S \S 7-403(\mathrm{a})(2)$, (b) (West 2012); N.Y. EdUC. LAW $\S 914(1)$ (McKinney 2007); N.Y. PUB. HEALTH LAw $\S \S 2164(8)-(9)$ (McKinney 2012); OHIO REV. CoDE ANN. $\S \S 3313.671(\mathrm{~A})(1)$, (B) (West 2012); 24 PA. Cons. STAT. AnN. $\S \S 13-1303 a(a),(c)-(d)$ (West 2006); VA. CodE AnN. $\S \S$ 22.1-271.2(A), -271.2(C), 32.1-46 (2014); see also Kimberly J. Garde, This Will Only Hurt For Ever: Compulsory Vaccine Laws, Injured Children, and No Redress, 3 PHOENIX L. REV. 509, app. A at 555-66 (2010) (listing statutes).

15. See Garde, supra note 14, at 518. Some states have exemptions for medical, religious, or philosophical reasons. See id. Two states, however, have exemptions for medical reasons only. See id.; see also Miss. CODE ANN. § 41-23-37 (2007); W. VA. CoDE $\S 16-3-4$ (2008). Depending on the rigor of the law, however, exemptions, even when allowed, may be difficult to obtain. See Steel, supra note 13, at 145 . Nevertheless, the constitutionality of required vaccination has been established. See, e.g., Jacobson v. Massachusetts, 197 U.S. 11, 26-27 (1905). 
vaccinated each week. ${ }^{16}$ Despite the public health benefits, ${ }^{17}$ vaccines are not free from risks. ${ }^{18}$ Because vaccines contain "attenuated viruses, chemical preservatives, and adjuvants," ${ }^{19}$ reactions occur that can lead to injury or even death. ${ }^{20}$ In fact, current evidence suggests that "between January 1990 and January 2010, at least 3,188 people died following vaccination; 5,123 people reported life-threatening injuries following vaccination; 5,603 people were permanently disabled following vaccination; and 129,763 people were hospitalized following vaccination, including prolonged hospitalization and emergency room visits." 21 These numbers are only those reported; some studies have estimated that these data encapsulate only between one and ten percent of actual adverse vaccine reactions. ${ }^{22}$

Before the advent of the VICP, those injured by vaccines turned to the courts, the only recourse available. ${ }^{23}$ As the number of government-

16. See Steel, supra note 13, at 145

17. Experts attribute a dramatic reduction in many diseases to mass-vaccination efforts. See, e.g., Garde, supra note 14, at 519-20. For example, "[p]rior to the availability of measles vaccines, nearly everyone in the United States contracted measles, yet only 450 deaths were reported each year from 1953-63; the CDC, however, predicts that completely stopping measles vaccinations would cause an annual death toll of 2.7 million people worldwide." Id. at 520 (citations omitted). "Prior to the availability of pneumococcal conjugate vaccines, 63,000 cases of pneumococcal disease with 6,100 deaths were reported each year in the United States; however, reports have decreased $75 \%$ since the introduction of the pneumococcal vaccine." Id. (citing What Would Happen If We Stopped Vaccinations?, CTRS. FOR DISEASE CONTROL \& PREV. (2003), http://www.cdc.gov/vaccines/vacgen/whatifstop.htm (last updated May 19, 2014)).

18. Boxler, supra note 12 , at 4 .

19. Id.; see, e.g., Brandon L. Boxler, What to Do With Daubert: How to Bring Standards of Reliable Scientific Evidence to the National Vaccine Injury Compensation Program, 52 WM. \& MARY L. REV. 1319, 1325 (2011).

20. Boxler, supra note 12, at 4.

21. Garde, supra note 14, at 526-27 (citing VAERS data, CDC WONDER On-line Database: Vaccine Adverse Event Reporting System, CTRS. FOR DISEASE CONTROL \& PREV., http://wonder. cdc.gov/vaers.html (last updated May 19, 2014)); see also infra note 181 (explaining VAERS data).

22. Garde, supra note 14, at 527 (citing CTR. For DRUG EVALUATION \& RESEARCH, FoOD \& Drug Admin., The Clinical Impact of AdVERSE Event Reporting 5 (1996), available at http://www.fda.gov/downloads/Safety/MedWatch/UCM168505.pdf); see Steven Rosenthal \& Robert Chen, The Reporting Sensitivities of Two Passive Surveillance Systems for Vaccine Adverse Events, 85 Aм. J. PUB. HEALth 1706, 1708 (1995), available at http://ajph.aphapublications.org /doi/pdf/10.2105/AJPH.85.12.1706 (finding that "reporting sensitivities for adverse [vaccine] events surveillance in the United States varied widely, ranging from $72 \%$ for vaccine-associated poliomyelitis to less than $1 \%$ for acute thrombocytopenic purpura following the MMR vaccine and hypotonic-hyporesponsive episodes following the DTP vaccine"); see also M. Miles Braun, Vaccine Adverse Event Reporting System (VAERS): Usefulness and Limitations, INSTITUTE FOR VACCINE SAFETY, www.vaccinesafety.edu/VAERS.htm (last updated Feb. 12, 2014) ("Underreporting is an inherent problem of passive surveillance systems, including VAERS.").

23. Some commentators have advanced the position that drug companies should not be held responsible at all for vaccine injuries as the companies are merely producing vaccines in compliance 
mandated vaccines increased, so did the injuries and lawsuits. ${ }^{24}$ These lawsuits alleged design defects, manufacturing defects, and other product liability causes of actions. ${ }^{25}$ The first major case was Gottsdanker v. Cutter Laboratories, ${ }^{26}$ involving two children who contracted poliomyelitis after receiving the Salk oral polio vaccine manufactured by Cutter Laboratories. ${ }^{27}$ The jury returned a verdict of $\$ 139,000$ for the children and $\$ 8,300$ in special damages for the parents. ${ }^{28}$ A few years later, in Tinnerholm v. Parke Davis \& Co., ${ }^{29}$ a federal district court awarded over $\$ 650,000$ for an infant who had suffered severe seizures, right-side paralysis, mental retardation, and other medical issues after vaccination. ${ }^{30}$

\section{The Effect of Vaccine Litigation on the Vaccine Market}

Because of these lawsuits, among others, ${ }^{31}$ and their attendant costs, pharmaceutical companies stopped, or threatened to stop, producing vaccines. $^{32}$ The reality was frightening for these pharmaceutical companies. For example, in 1984, Lederle was the only commercial manufacturer of the diphtheria, tetanus, and pertussis vaccine, and its potential legal liability exposure was more than two hundred times its annual sales. ${ }^{33}$ The vaccine manufacturers' legal defense costs in 1984

with federal standards. See Steel, supra note 13, at 146. To support this position, they argue that because society as a whole benefits from vaccination, "society" should bear the costs. See id.

24. Boxler, supra note 12, at 6. For example, one authority has the number of vaccine lawsuits in 1980 at 24, and in 1985 that number rose to 150. See id. (citing Mary Beth Neraas, Comment, The National Vaccine Injury Act of 1986: A Solution to the Vaccine Liability Crisis?, 63 WASH. L. REV. 149, 151 \& n.15 (1988)).

25. See, e.g., RESTATEMENT (SECOND) OF TORTS $\S 402 A$ (1965) (noting liability of seller for defective products causing physical harm to user).

26. 6 Cal. Rptr. 320, 322 (Cal. Dist. Ct. App. 1960).

27. "Poliomyelitis" is "[a]n inflammatory process involving the gray matter of the cord." Stedman's MediCAL DiCtionary 1400 (26th ed. 1995). See Gottsdanker, 6 Cal. Rptr. at 322.

28. Id.

29. 285 F. Supp. 432 (S.D.N.Y. 1968).

30. Id. at $437,454$.

31. See, e.g., Reyes v. Wyeth Labs., 498 F.2d 1264 (5th Cir. 1974); Davis v. Wyeth Labs., 399 F.2d 121 (9th Cir. 1968); see also Morris v. Parke, Davis \& Co., 573 F. Supp. 1324, 1325, 1330 (C.D. Cal. 1983) (permitting even punitive damages under a market share theory).

32. Boxler, supra note 12 , at 6.

33. Id. at 6-7. Some manufacturers, such as Connaught and Wyeth, even stopped making the DPT vaccine. See Jaclyn S. Levine, Note, The National Vaccine Injury Compensation Program: Can It Still Protect An Essential Technology?, 4 B.U. J. SCI. \& TECH. L. 9, n.7 (citing 131 Cong. Rec. S3843-04 (daily ed. Apr. 2, 1985) (statement of Sen. Hawkins)). 
were estimated at $\$ 9.8$ million. $^{34}$ To make up for this exposure gap, naturally, vaccine prices increased. To illustrate, "[t]he price of a dose of DPT rose from ten cents in 1982 to more than $\$ 3.00$ in 1986." 35 Other estimates have vaccine prices skyrocketing by 2,000 percent. $^{36}$ Consequently, Congress entered the fray in the belief that the legal system's "failure" to adjudicate these claims combined with the effect on the vaccine market constituted a public health emergency. ${ }^{37}$ Congress therefore enacted the National Childhood Vaccine Injury Compensation Act of 1986, which created the VICP. ${ }^{38}$

\section{B. The Vaccine Act and the Vaccine Injury Compensation Program}

The goals of the Act, according to its legislative history, are twofold: (1) to ensure adequate compensation for those injured by vaccines and (2) to promote stability in the vaccine market. ${ }^{39}$ To achieve these goals, the federal government acts as a financial backstop. The system put in place by the Act has two separate but related parts. Part one of the system establishes the "no fault" compensation scheme, ${ }^{40}$ the impetus being to make awards to "vaccine-injured persons quickly, easily, and with certainty and generosity." 41 The money for this part of the VICP comes from a tax levied on designated vaccines. ${ }^{42}$ Part two of the system establishes additional remedies should the injured person reject an award under the VICP. ${ }^{43}$

At base, the Act effectuates its policy by exclusion. In other words, an injured person cannot pursue a traditional common-law tort action against a vaccine manufacturer until that person completes the VICP

34. See Staff of Subcomm. on Health \& the EnV'T of the H. Comm. on Energy \& COMmerce, 99th Cong., ReP. ON Childhood ImMunizations 87 (Comm. Print 1986); see also Steel, supra note 13, at 153 .

35. Steel, supra note 13, at 153 n.100 (citing Okianer C. Dark, Is the National Childhood Vaccine Injury Act of 1986 the Solution for the DTP Controversy?, 19 U. TOL. L. REV. 799, 855 (1988)).

36. See H.R. REP. No. 101-247, at 509 (1989), reprinted in 1989 U.S.C.C.A.N. 1906, 2235; see also Randall B. Keiser, Déjà vu All Over Again? The National Childhood Vaccine Injury Compensation Act of 1986, 47 FoOD \& DRUG L.J. 15, 16 (1992).

37. Boxler, supra note 12 , at 7 .

38. 42 U.S.C. $\S \S 300 \mathrm{aa}-1$ to -34 (2012)

39. H.R. REP. NO. 99-908, at 7 (1986), reprinted in 1986 U.S.C.C.A.N. 6344, 6348.

40. Id. at 3 .

41. Id.

42. Id.

43. $I d$. 
process. $^{44}$ The Act's hope, of course, is that the injured person will accept the compensation allowed under the Act through the VICP and will not resort to the common-law tort action.

Under the Act, "[a] proceeding for compensation under the [VICP] for a vaccine-related injury or death" is initiated by serving the Secretary of Health and Human Services with a petition for compensation and paying the filing fee. ${ }^{45}$ In the petition, the petitioner is required to demonstrate that the person received the vaccine in the United States; sustained or aggravated any illness, disability, or injury (and the date of onset); ${ }^{46}$ suffered the residual effects of such illness for more than six months after the date of vaccination; and has not previously collected an award or settlement for the vaccine injury. ${ }^{47}$ In addition, the petitioner is required to submit a plethora of medical records. ${ }^{48}$

After the petition is filed, the Act gives the Court of Federal Claims, acting through the court's Office of Special Masters, "jurisdiction over [the] proceedings to determine if a petitioner... is entitled to compensation under the [VICP] and the amount of such compensation." 49 The petition is assigned to a special master, who is to "issue a decision on such petition with respect to whether compensation is to be provided under the [VICP] and the amount of such

44. See 42 U.S.C. $§ 300 a a-11(a)(2)(A)$ (2012) ("No person may bring a civil action for damages in an amount greater than $\$ 1,000$ or in an unspecified amount against a vaccine administrator or manufacturer in a State or Federal court for damages arising from a vaccine-related injury or death associated with the administration of a vaccine after October 1, 1988, and no such court may award damages in an amount greater than $\$ 1,000$ in a civil action for damages for such a vaccine-related injury or death, unless a petition has been filed, in accordance with section 300aa-16 of this title, for compensation under the Program for such injury or death . ...”).

45. Vaccine Rules of the U.S. Court of Federal Claims 2, app. B of the Rules of the Court of Federal Claims, available at http://www.uscfc.uscourts.gov/sites/default/files/court_info/ 20130813_rules/13.08.30\%20Final\%20Version\%20of\%20Vaccine\%20Rules.pdf [hereinafter FED.

CL. VACCINE R.].

46. The date of onset is paramount for statute of limitations purposes. It is not the act of vaccination that triggers the beginning of the statute of limitations period; it is the date of symptom onset. 42 U.S.C. § 300aa-16(a)(2) (2012); see also Markovich v. Sec'y of Health \& Human Servs., 477 F.3d 1353, 1357 (Fed. Cir. 2007) ("Under the plain language of the Vaccine Act, the "first symptom or manifestation of onset' of injury means that either a 'symptom' or a 'manifestation of onset' can trigger the running of the statute, whichever is first. Because Congress is presumed to have intended a disjunctive meaning by using the disjunctive word 'or,' we interpret the words 'first symptom' and 'manifestation of onset' as referring to two different forms of evidence of injury.").

47. See 42 U.S.C. $\$ 300 a a-11$ (c) (2012); see also FED. CL. VACCINE R. 2(c) (prescribing the contents of a petition).

48. See 42 U.S.C. § 300aa-11(c).

49. Id. $\S 300 \mathrm{aa}-12(\mathrm{a})$. 
compensation." ${ }^{50}$ The decision is required to contain findings of fact and conclusions of law, and it is to be rendered generally within 240 days after the petition is filed. ${ }^{51}$

To come to the statutorily required decision regarding compensation, the Act allows the special master to conduct a proceeding, ${ }^{52}$ through which the special master may order the parties to submit testimony, evidence, or other information deemed relevant. ${ }^{53}$ The special master is not bound by rules of evidence or even required to allow direct or crossexaminations; rather, all that is required is for the special master to consider "all relevant and reliable evidence governed by principles of fundamental fairness to both parties." fact, to "make the proceedings expeditious, flexible, and less adversarial ...."55 In sum, the special master presides over a quasijudicial proceeding. ${ }^{56}$

The Act commands that "[c]ompensation shall be awarded" if the special master or court finds that the petitioner has demonstrated by a preponderance of the evidence the matters that are required to be alleged in the petition, and if there is no non-vaccine cause for the illness or injury. ${ }^{57}$

Because part of the Act is a no-fault system for compensation, the Act relaxes the petitioner's traditional civil burdens in some ways. The Act has a "vaccine table" that allows a "finding of causation in a field

50. Id. $\S 300$ aa-12(d)(3)(A). The Secretary is also to provide a report within thirty days noting whether any required documentation is missing and provide a report within ninety days setting forth its position regarding the payment of compensation. FED. CL. VACCINE R. 4.

51. Id.; FED. CL. VACCINE R. 10. There is some evidence, however, that this time frame is not being complied with. See Peter H. Meyers, Fixing the Flaws in the Federal Vaccine Injury Compensation Program, 63 ADMIN. L. REV. 785, 789 (2011) (noting that "virtually no cases are concluded within the 240-day deadline ....”).

52. Such a proceeding is not required, however. See FED. CL. VACCINE R. 8(d); Burns ex rel. Burns v. Sec'y of Health \& Human Servs., 3 F.3d 415, 417 (Fed. Cir. 1993).

53. 42 U.S.C. $\S 300 a a-12(d)(3)(B)$.

54. FED. CL. VACCINE R. 8(b), 3(b); see also 42 U.S.C. $§ 300 a a-12(d)(3)(B)$.

55. FED. CL. VACCINE R. 3(b)(2).

56. Some commentators have argued that the VICP is becoming "too adversarial," and is therefore contrary to the original purpose and intent of the VICP. See, e.g., Meyers, supra note 51, at 808-09; Lawrence O. Gostin \& Benjamin E. Berkman, Pandemic Influenza: Ethics, Law, and the Public's Health, 59 ADMIN. L. REV. 121, 136 (2007) ("Moreover, [the] VICP has become adversarial, burdensome on claimants, and time consuming."); see also Lawrence O. Gostin, Medical Countermeasures for Pandemic Influenza: Ethics and the Law, 295 J. AM. MED. Ass'N 554, 555 (2006).

57. 42 U.S.C. $\$ 300 a a-13$.

58. See id. $\S 300 a a-14(a)$; see also 42 C.F.R. $\S 100.3$ (2013). The Secretary is authorized to amend the table as necessary based on the advice of, inter alia, the Advisory Commission on 
bereft of complete and direct proof of how vaccines affect the human body." 59 Thus, petitioners can establish an entitlement to compensation by, inter alia, proving that they suffered a specific injury on the vaccine table; this is known as a "table injury" case. If a petitioner shows by a preponderance of the evidence that he or she received an injury listed on the table within the requisite time frame, the petitioner is presumptively entitled to compensation. ${ }^{60}$ For example, if a petitioner went into anaphylactic shock within twenty-four hours of receiving a DTP vaccine, she would be entitled to a presumption of compensation. ${ }^{61}$ To rebut the presumption, the government has the burden to show some non-vaccine cause of the injury. ${ }^{62}$

If, however, the claimant cannot establish a table injury, the petitioner can proceed "off table." ${ }^{\text {"63 }}$ In this scenario, as in traditional tort liability, the petitioner must prove, by a preponderance of the evidence, that the vaccine is the "but for" cause and a substantial factor in bringing about that injury. ${ }^{64}$ This approach naturally may require medical experts, ${ }^{65}$ and like any other pharmaceutical defect case, it can become a costly and time-intensive endeavor. A petitioner need not, however, eliminate all possible alternate causes of injury. ${ }^{66}$

Childhood Vaccines. 42 U.S.C. $\S \S 300 a a-14(c)(2),-19$.

59. Althen v. Sec'y of Health \& Human Servs., 418 F.3d 1274, 1280 (Fed. Cir. 2005).

60. See, e.g., Andreu ex rel. Andreu v. Sec'y of Health \& Human Servs., 569 F.3d 1367, 1374 (Fed. Cir. 2009) ("In a table claim, a claimant who shows that he or she received a vaccination listed in the Vaccine Injury Table . . . and suffered an injury listed in the table within a prescribed period is afforded a presumption of causation.").

61. 42 U.S.C. $\S 300 a a-14(a)(I)(A)$.

62. See, e.g., Pafford v. Sec'y of Health \& Human Servs., 451 F.3d 1352, 1355 (Fed. Cir. 2006) ("[T]he burden shifts to the respondent to prove that a factor unrelated to the vaccination actually caused the illness, disability, injury, or condition.").

63. Recently, most cases in the VICP have been "off table." See Meyers, supra note 51, at 798 (noting that from 2007 to 2010 , "almost $90 \%$ of the petitions filed assert only non-Table injuries").

64. Moberly ex rel. Moberly v. Sec'y of Health \& Human Servs., 592 F.3d 1315, 1321-22 (Fed. Cir. 2010) ("[A] petitioner in a Vaccine Act case must show that the vaccine was "not only a but-for cause of the injury but also a substantial factor in bringing about the injury.", (quoting Shyface v. Sec'y of Health \& Human Servs., 165 F.3d 1344, 1352-53 (Fed. Cir. 1999))). In Althen v. Sec'y of Health \& Human Servs., 418 F.3d 1274, 1278 (Fed. Cir. 2005), the Federal Circuit held that the petitioner, in proceeding off-table, must establish "(1) a medical theory causally connect[s] the vaccination and the injury; (2) a logical sequence of cause and effect show [s] that the vaccination was the reason for the injury; and (3) a showing of a proximate temporal relationship between [the] vaccination and the injury."

65. Petitioners need not prove their case with scientific certainty. See Althen, 418 F.3d at 1280 (noting that requiring medical literature to prove causation would impermissibly raise the plaintiff's burden of proof).

66. See Shyface, 165 F.3d at 1351 (noting that in determining whether "[an] injury was not caused by factors unrelated to the vaccine, the court [does not need] to include speculative or 
Assuming a petitioner is successful, either in a table or off-table case, the Act mandates the payment of compensation. Allowable "compensation" under the Act is defined by statute. ${ }^{67}$ Statute 42 U.S.C. $\S 300$ aa-15 prescribes that an award of compensation "shall" include seven possible items. The first item is actual unreimbursable expenses incurred from the date of the judgment and reasonable projected unreimbursable expenses that are attributable to the vaccine-related injury, including medical care, diagnosis, and an array of rehabilitation services, namely, traditional compensatory-type damages. ${ }^{68}$ The second item is actual unreimbursable expenses incurred before the date of the judgment that resulted from the vaccine-related injury, including medical and remedial care. ${ }^{69}$ The third item of compensation arises only in the case of a vaccine-related death and is a payment of $\$ 250,000$ to the estate of the deceased. ${ }^{70}$ The fourth item, the actual and anticipated loss of earnings, is for petitioners over eighteen years old who, due to the vaccine-related injury, have suffered a diminution in earning potential. ${ }^{71}$ The fifth item, designed to simulate the earnings of an average worker in the private sector (after certain withholdings), is for petitioners under eighteen years old who have an injury so severe that it is likely to impair earning potential at the age of eighteen and beyond. ${ }^{72}$ The sixth item is for actual and projected pain and suffering but is not to exceed $\$ 250,000 .^{73}$ Finally, seventh, if compensation is awarded-i.e., if the petition is successful on the merits - the Act also directs the special master to award, "as part of such compensation," an amount to cover reasonable attorneys' fees and other costs. ${ }^{74}$

After the special master issues the decision on the merits, either party can file a motion with the clerk of court for a judge of the United States Court of Federal Claims to review the special master's decision. ${ }^{75}$

\footnotetext{
hypothetical matters or explanations.").

67. 42 U.S.C. $\$ 300 a a-15(2012)$.

68. Id. $\S 300 \mathrm{aa}-15(\mathrm{a})(1)(\mathrm{A})$.

69. Id. $\S 300 \mathrm{aa}-15(\mathrm{a})(1)(\mathrm{B})$.

70. Id. § 300aa-15(a)(2).

71. Id. §300aa-15(a)(3)(A).

72. Id. § 300aa-15(a)(3)(B).

73. Id. §300aa-15(a)(4).

74. Id. $\S 300$ aa-15(e) (providing that attorneys' fees may be granted even if the petitioner is not successful on the merits if the special master finds that the petition was brought in good faith and that there was a reasonable basis for the underlying claim in the petition). See infra Parts III.A and III.E.

75. Id. §300aa-12(e)(1).
} 
During this review, the judge can uphold the special master's findings of fact and conclusions of law, thereby sustaining the decision; the judge can set aside findings of fact or conclusions of law and issue the court's own findings and conclusions; or the judge can remand the petition to the special master for further proceedings. ${ }^{76}$

Interestingly, unlike other fee-shifting statutes, non-prevailing petitioners can still be awarded attorneys' fees and costs. ${ }^{77}$ Under 42 U.S.C. $\S 300$ aa-15(e)(1), a petitioner may request attorneys' fees, even if he or she does not prevail on the merits, as long as the claim was brought in "good faith" and with a "reasonable basis." 78 This, in part, is what creates the moral hazard problem in the VICP.

\section{The Problem of Pre-MERIT-DeCision INTERIM FEE AWARDS IN THE VICP}

\section{A. Overview of the Problem}

The hopeful path of a petition under the Act is intended to be relatively simple, especially for a table injury. The petitioner collects all of the medical records, fills out the petition, and files the paperwork; if everything is in order, the government likely will not oppose the payment of compensation, because that's why the money is available - to be doled out to those injured by vaccines. The special master will award compensation based on the allowable elements in 42 U.S.C. $\S 300 \mathrm{aa}-15$, and, if an attorney is involved, issue attorneys' fees too. As long as there is no dispute from the government, that's it - case over. For a growing percentage of cases in the VICP, however, that's not how it's working. ${ }^{79}$

There are two major problems with the current operation of the VICP due to the Federal Circuit's interpretation of the Act. The first problem is the allowance of pre-merit-decision interim attorneys' fees - that is, attorneys' fees and costs that are paid-with tax dollars-before any decision is rendered on the merits of the petition, either favorably or unfavorably. The second problem is the standard (or lack thereof) used

\footnotetext{
76. Id. §300aa-12(e)(2).

77. See, e.g., Avera v. Sec'y of Health \& Human Servs., 515 F.3d 1343 (Fed. Cir. 2008).

78. See id. at 1346.

79. See, e.g., National Vaccine Injury Compensation Program Statistics Report, Health ReS. \& SERVS. ADMIN., http://www.hrsa.gov/vaccinecompensation/statisticsreports.html (last updated Mar. 5, 2014) [hereinafter VICP Statistics] (showing growing number of interim fee cases); see also infra Part III.B (explaining how interim fee cases complicate cases and clog the court's docket).
} 
to decide whether to issue interim fees. For the first twenty-six fiscal years that the VICP operated, it paid nearly $\$ 180$ million in attorneys' fees and costs. ${ }^{80}$ For the first nineteen of those years, however, not a single dime of interim fees (whether pre- or post-merit) was paid. ${ }^{81}$ That all changed, however, with the Federal Circuit's decisions in Avera v. Secretary of Health \& Human Services ${ }^{82}$ and Shaw v. Secretary of Health \& Human Services. ${ }^{83}$ Since those cases, the VICP has paid over $\$ 16.5$ million in "interim fees." 84 These two cases, therefore, have served as a license, allowing the special masters to dole out taxpayer money in a radically different fashion than that historically allowed under the Act. In fact, interim attorneys' fees and costs account for nearly one-fifth of all fees and costs awarded over that same time period.

\section{B. Moral Hazard Encourages Extra Litigation and Potential "Churning" in the VICP}

There are myriad public policy concerns with the advent and growth of pre-merit-decision interim fee litigation in the VICP. Chief of these problems is that this litigation increases the moral hazard already structurally built into the VICP. ${ }^{85}$ Moral hazard is the economic phenomenon that insurance against loss reduces incentives to prevent or mitigate that loss. ${ }^{86}$ Here, the insurance is the multiple levels of "free" judicial review (special masters, Court of Federal Claims, Federal Circuit, and Supreme Court) and the economic loss (or lack thereof) is the cost of litigation, which is now picked up by the taxpayer, not the

80. Id. Granted, this total seems small in comparison to the over \$2.6 billion in merit awards that the VICP paid out for merit decisions. Id.

81. Id.

82. 515 F.3d 1343 (Fed. Cir. 2008).

83. 609 F.3d 1372 (Fed. Cir. 2010).

84. VICP Statistics, supra note 79. The table providing for the payment of attorneys' fees does not indicate whether these are all pre-merit-decision fees or include fees for cases that are pending appeal and might still be considered "interim." Based on the current usage of "interim" in the VICP, however, there is a strong likelihood that this does mean pre-merit-decision fees.

85. Commentators have already noted the moral hazards of the VICP. See generally Boxler, supra note 12 .

86. Tom Baker, On the Genealogy of Moral Hazard, 75 TEX. L. REV. 237, 239 (1996) ("“[M]oral hazard' refers to the tendency for insurance against loss to reduce incentives to prevent or minimize the cost of loss."); see also Boxler, supra note 12, at 25. Others have defined moral hazard as a situation in which "one party is responsible for the interests of another, but has an incentive to put his or her own interests first." Kevin Dowd, Moral Hazard and the Financial Crisis, 29 CATO J. 141,142 (2009). 
plaintiff or plaintiff's counsel as in traditional civil litigation. ${ }^{87}$ Basically, the person who makes the decision to litigate (the petitioner or petitioner's lawyer) is not the one who ultimately bears the economic risk of loss (litigation costs).

Commentators have lambasted the Vaccine Act for its inherent moral hazard problem - namely, the shifting of litigation fees from private parties to the taxpayer. ${ }^{88}$ This statutory scheme, as some have noted, creates "perverse incentives." ${ }^{\prime 9}$ With automatic fees if you win-and basically automatic fees if you $\operatorname{lose}^{90}$ - there is no reason to ever stop litigating in the VICP! ${ }^{91}$ There are multiple levels of appellate review for both the merit decision and now, on top of that, the pre-merit-decision interim fee decision. Thus, there is little downside - at least no economic downside - for an opportunistic attorney, who can exhaust every option on every issue at the ultimate expense of the taxpayer. ${ }^{92}$

While commentators have noted the moral hazard problem regarding financially riskless appeals on merit decisions in the VICP,${ }^{93}$ nobody has addressed the particular problem regarding pre-merit-decision interim fees. The moral hazard problem on interim fees is even more troubling, as the fees inure only to the lawyer: there is no potential upside or economic gain for the client. In multiple levels of appellate review on merit decisions, there is at least a chance that one of the Court of Federal Claims or Federal Circuit judges could find favorably for the petitioner on the merits, and therefore substantively change the outcome on compensation. By definition, however, that cannot happen on pre-meritdecision interim fee review - the underlying merit decision has not yet been reached and therefore cannot be changed. The only one who can possibly benefit is the petitioner's counsel at the expense of the taxpayer.

Because there is no financial risk to pursuing these claims, including pre-merit-decision interim fees, this unnecessarily clogs and burdens the special masters' and judges' dockets of the court. ${ }^{94}$ For instance, for

\footnotetext{
87. See Boxler, supra note 12, at 24-25.

88. See generally id.

89. See id. at 24.

90. See infra Part III.E (discussing McKellar and the standard for interim fees).

91. Boxler, supra note 12, at 24 .

92. Some have argued that the many levels of financially riskless appeals on merits decisions in the VICP effectively makes the special master decision precatory because a Court of Federal Claims or Federal Circuit judge almost invariably will be the ultimate decider of the case. See id. at

93. See id. at $25-26$.

94. See, e.g., Meyers, supra note 51, at 848 ("The payment of attorneys' fees and costs has
} 26. 
fiscal year 2012, there were 250 successful VICP awards, ${ }^{95}$ and there were 37 interim fee awards, ${ }^{96}$ for a ratio of 7:1. In 2008-just a few years earlier - that ratio was $71: 1 .^{97}$ What can be inferred, in part, from this admittedly small sample size is that, everything else being equal, in 2012 (compared to 2008) less of the court's time was likely spent on adjudicating merit-based claims - which is the mission of the VICP. Time and the fixed resources of the court's staff are being spent away from merit decisions to adjudicate these pre-merit-decision interim award disputes at multiple levels of review.

The current interpretation of the Act, leading to the moral hazard problem, also encourages "churning"-that is, the practice of intentionally driving up fees and expenses unnecessarily. In the financial services context, for example, this occurs when a broker trades a stock many times, unnecessarily, to drive up commissions and fees. ${ }^{98}$ Simply put, it is a situation where the agent benefits to the detriment of the principal. Because the standard - if we can actually call it that-for interim fees is so loose and lawyer-friendly, ${ }^{99}$ it encourages (in theory) passing a file from lawyer to lawyer and thereby driving up the costs of representation, ${ }^{100}$ or to take a case and spend money on it that the lawyer would not otherwise spend. The client does not care, as the client is not

generated considerable litigation in the Vaccine Program.").

95. VICP Statistics, supra note 79.

96. Id.

97. Id.

98. Larry A. Cerutti, SEC Rule 10b-16: Should the Federal Courts Allow Sophisticated Investors to Recover?, 18 PAC. L.J. 171, 192 (1986) ("Churning occurs when a broker, acting in his or her own interests, engages in excessive trading of an account to generate commissions without regard to the investment objectives of the customer."); Norman S. Poser, Options Account Fraud: Securities Churning in a New Context, 39 Bus. LAw. 571, 571 (1984) ("Churning . . occurs when a securities broker or dealer who controls the volume and frequency of trading in a customer's account abuses the customer's confidence for his own personal gain in order to increase the amount of commissions by initiating transactions that are excessive in view of the financial situation and investment objectives of the customer."); Note, Churning by Securities Dealers, 80 HARV. L. REV. 869,869 (1967) ("The 'churning' of a securities account occurs when a dealer, acting in his own interests and against those of his customer, induces transactions in the customer's account which are excessive in size and frequency in light of the character of the account."); see also Thompson v. Smith Barney, Harris Upham \& Co., 709 F.2d 1413, 1416 (11th Cir. 1983) ("Churning occurs when a securities broker buys and sells securities for a customer's account, without regard to the customer's investment interests, for the purpose of generating commissions.").

99. See discussion infra Part III.E.

100. The author does not represent that any lawyer in any of the cited cases in this Article engaged in unnecessary billing, churning, or otherwise improper use of the VICP. Rather, the author intends to convey that the current operation of the VICP - contrary to its historic practiceimplicitly encourages such conduct to occur, either intentionally or unwittingly. 
footing the bill. The problem of moral hazard yet again rears its ugly head, and the taxpayer is left with the tab. ${ }^{101}$

\section{Pre-Merit-Decision Interim Fee Awards Create Disincentives for Lawyers to Finish Cases}

The case law has established that an attorney can even withdraw from the representation-before the merits of the case are even decided - and still be paid attorneys' fees by the VICP. ${ }^{102}$ This is exactly what the special master was willing to do in McKellar v. Secretary of Health \& Human Services. ${ }^{103}$ After McKellar, this has become even more common. ${ }^{104}$ Admittedly, an attorney can withdraw in traditional civil litigation and still be paid fees by the client, but in that situation the moral hazard calculus is drastically different because either the attorney or the plaintiff is bearing the risk of loss; this reduces the likelihood of pursuing meritless cases in the first instance. In the VICP, however, that financial risk of loss is borne by the taxpayer - so the attorney has no

101. Of course, the government always has the option to object to fees as excessive or unnecessary. However, it would strain credulity to believe that the government is always able to ferret out unnecessary or dishonest fee requests. Moreover, since it is not the government lawyer's money on the table, the moral hazard problem still arises nevertheless.

102. See, e.g., Hiland v. Sec'y of Health \& Human Servs., No. 10-491V, 2012 WL 542683 (Fed. Cl. Spec. Mstr. Jan. 31, 2012). Judge Bruggink, however, tried to limit the availability of pre-meritdecision interim fees to withdrawing counsel. See McKellar v. Sec'y of Health \& Human Servs., 101 Fed. Cl. 297, 301 (2011). There, Judge Bruggink construed Avera to mean that "some special showing is necessary to warrant interim fees, including but not limited to the delineated factors of protracted proceedings, costly experts, or undue hardship. If mere good faith and reasonable basis were all that is necessary, the Avera factors become superfluous and interim fees would be the norm." Id. His words were prophetic-interim fees are now the norm in the program. Some special masters have expressly eschewed Judge Bruggink's reasoning in McKellar. See, e.g., Hiland, 2012 WL 542683, at *6 ("To the extent that the court in McKellar held that withdrawal of an attorney is not a circumstance in which an interim fee award is appropriate, the undersigned respectfully disagrees.").

103. No. 09-841V, 2011 WL 3425606 (Fed. Cl. Spec. Mstr. Jun. 3, 2011), rev'd, 101 Fed. Cl. 297 (2011); see also infra Part III.E (discussing McKellar in more detail).

104. See, e.g., Stumpf v. Sec'y of Health \& Human Servs., No. 02-1711V, 2011 WL 6890165 (Fed. Cl. Spec. Mstr. Nov. 4, 2011) (granting interim fees to withdrawing counsel); Coiro-Lorusso v. Sec'y of Health \& Human Servs., No. 04-258V, 2011 WL 6000600 (Fed. Cl. Spec. Mstr. Oct. 5, 2011) (same); Loutos v. Sec'y of Health \& Human Servs., No. 03-355V, 2011 WL 6000775 (Fed. Cl. Spec. Mstr. Oct. 5, 2011) (same); Lockhart v. Sec'y of Health \& Human Servs., No. 02-1416V, 2011 WL 5299242 (Fed. Cl. Spec. Mstr. Sept. 29, 2011) (same); Feld v. Sec'y of Health \& Human Servs., No. 02-1319V, 2011 WL 5248341 (Fed. Cl. Spec. Mstr. Sept. 28, 2011) (same); DyerAlexander v. Sec'y of Health \& Human Servs., No. 04-293V, 2011 WL 5299039 (Fed. Cl. Spec. Mstr. Sept. 28, 2011) (same); Moriarty v. Sec'y of Health \& Human Servs., No. 03-257V, 2011 WL 5299249 (Fed. Cl. Spec. Mstr. Sept. 28, 2011) (same); Deliberis ex rel. Deliberis v. Sec'y of Health \& Human Servs., No. 01-613V, 2011 WL 5299423 (Fed. Cl. Spec. Mstr. Sept. 28, 2011) (same). 
incentive not to take a case! This is compounded further by the subjective approach to granting interim fees; attorneys can almost be guaranteed payment of interim fees as long as there was no express knowledge that the case was frivolous. ${ }^{105}$

Moreover, in many cases, when the attorney withdraws, the petitioner is forced to act pro se. Pro se litigants are at a disadvantage in traditional civil litigation. ${ }^{106}$ The VICP is foreign to most lawyers; how is a pro se litigant supposed to ably navigate its procedure and substance?

One of the policies given lip service in granting these pre-meritdecision interim fees was to provide an able bar of attorneys for those injured-recognizing that attorneys knowledgeable in the Act and the VICP are assuredly a boon to those injured. But now that policy is turned on its head, as there is now a real financial incentive to leave the case pre-merit-decision - the very decision that is most important. This concern is particularly valid when the case involves a non-table injury, that is, when the petitioner has to prove causation. Often this is accomplished by expert testimony, submission of scientific studies, and the panoply of evidence traditionally used in civil medical malpractice and pharmaceutical defect cases. These are the most complicated and costly cases but now the attorney - if he or she thinks the case may not be a sure winner-has an incentive to get out before investing the costs in compiling all that evidence and testimony-and he will still get paid. ${ }^{107}$ This does not leave those injured in a favorable position, and thus runs counter to the purpose of the VICP.

\footnotetext{
105. See discussion infra Part III.E.

106. See, e.g., Judith G. McMullen \& Debra Oswald, Why Do We Need a Lawyer? An Empirical Study of Divorce Cases, 12 J.L. \& FAM. STUD. 57, 78 (2010) (finding that "maintenance was most likely to be awarded in cases where both husband and wife had representation"); Richard W. Painter, Pro Se Litigation in Times of Financial Hardship - A Legal Crisis and Its Solutions, 45 FAM. L.Q. 45, 46 (2011) (noting an ABA study finding that "[s]ixty-two percent of the judges [surveyed] said that outcomes were worse for the unrepresented parties; while $37 \%$ of the judges said there was no impact from lack of representation; and 3\% said that outcomes were better."); see also ABA COAL. FOR JUSTICE, REPORT ON THE SURVEY OF JUDGES ON THE IMPACT OF THE ECONOMIC DOWNTURN ON REPRESENTATION IN THE COURTS (2010), available at http://www.americanbar.org/content /dam/aba/migrated/JusticeCenter/PublicDocuments/CoalitionforJusticeSurveyReport.authcheckdam. pdf (finding that significant percentages of judges surveyed found pro se litigants were underprepared and needed staff assistance); Rafael I. Pardo, An Empirical Examination of Access to Chapter 7 Relief by Pro Se Debtors, 26 EMORY BANKR. DEV. J. 5, 23 (2009) (noting a higher percentage of pro se petitions are dismissed in bankruptcy than those represented by counsel); Carroll Seron, Martin Frankel, Gregg Van Ryzin \& Jean Kovath, The Impact of Legal Counsel on Outcomes for Poor Tenants in New York City's Housing Court: Results of a Randomized Experiment, 35 LAW \& SOC'Y REV. 419, 429 (2001) (finding a correlation between legal representation and the likelihood of a favorable judicial outcome).

107. This of course is subject to rules of professional conduct that allow counsel to withdraw if,
} 
The United States is liable only to the extent of the VICP trust funds. ${ }^{108}$ As pre-merit-decision interim fees are paid, this leaves less money in the trust fund for merit compensation. Therefore, as this Article demonstrates, awarding pre-merit-decision interim fees is contrary to the historic norm under the VICP and is deleterious to the VICP and those who are to be served by it. Pre-merit-decision interim fee payments therefore need to be stopped.

\section{How We Got Here: The Judicial Genesis of Pre-Merit-Decision Interim Fees}

\section{Avera v. Secretary of Health \& Human Services}

Avera v. Secretary of Health \& Human Services is the genesis for "interim fees." I09 It is important to note that although Avera used the phrase "interim fees," the VICP uses that term today in a completely different way. ${ }^{110}$ In 2004, the Averas filed a petition on behalf of their son, Connor, and alleged that Connor had suffered encephalopathy in response to a number of vaccines he received in 2001. ${ }^{111}$ The petition alleged two claims: a table claim and a cause-in-fact claim. ${ }^{112}$ Petitioners later abandoned the table claim but pursued the cause-in-fact claim. ${ }^{113}$ Over a year after the petition had been filed, and after several extensions from the special master, the Averas finally admitted that they were unable to find a validating medical expert opinion to support the causein-fact claim. ${ }^{114}$ The Averas then requested that the special master render a decision based on the then-current state of the medical reports and

\footnotetext{
inter alia, "withdrawal can be accomplished without material adverse effect on the interests of the client" or "other good cause for withdrawal exists." See Model Rules OF PROF'L CONDUCT R. 1.16(b)(1), (7) (2013); see also Lumsden ex rel. Peters v. Sec'y of Health \& Human Servs., No. 970588V, 2012 WL 1357504, at *2 (Fed. Cl. Spec. Mstr. Mar. 29, 2012) (examining Model Rules of PROF'L CONDUCT R. 1.16).

108. See 26 U.S.C. $\S 9510(d)(1)(2012)$.

109. 515 F.3d 1343 (Fed. Cir. 2008).

110. The prime distinction is that the "interim fees" in Avera were still post-merit decision, i.e., the special master had already issued a decision on the underlying petition. This is completely different from the practice today in the VICP.

111. Encephalopathy refers to "[a]ny disorder of the brain." STEDMAN's MEDiCAL DictionaRY, supra note 27, at 566. Avera ex rel. Avera v. Sec'y of Health \& Human Servs., No. 04-1385, 2005 WL 6117662, at*1 (Fed. Cl. Spec. Mstr. Dec. 21, 2005).

112. Id

113. $I d$

114. Id.
} 
record. ${ }^{115}$ On December 21, 2005, the special master held that the petitioners were not entitled to compensation under the Act. ${ }^{116}$

That was not the end of the case, however. In February 2006, the Averas filed an application for an award of attorneys' fees. ${ }^{117}$ The fees sought reflected an hourly rate based on Cheyenne, Wyoming, where the Averas' counsel lived and worked. ${ }^{118}$ The lawyers' rates per hour were $\$ 200, \$ 130$, and $\$ 100$, depending on the experience level of the particular lawyer. ${ }^{119}$ But while that fee request was pending, the Averas submitted an amended fee petition, which was identical in all respects except for the per-hour rates. ${ }^{120}$ Now counsel sought to apply Washington, D.C., rates, using the Laffey Matrix, ${ }^{121}$ and requested fees ranging from $\$ 130$ to $\$ 598$ per hour, depending on the lawyer's experience. $^{122}$

The special master awarded the fees at the original Cheyenne rates, holding that he was bound to follow the "traditional geographic rule" of the U.S. Court of Federal Claims. ${ }^{123}$ The Averas filed a motion to vacate the special master's fee decision, again arguing that they were entitled to the higher Washington, D.C., rates. ${ }^{124}$ It was at this point, for the first time, that the Averas asserted they were entitled to an award of "interim fees" pending appeal. ${ }^{125}$

The Averas sought review in the Court of Federal Claims. ${ }^{126}$ The court held that it would be improper to use District of Columbia rates, as counsel had little to no actual contact with the District - all of the legal services were actually performed in Cheyenne. ${ }^{127}$ Regarding "interim

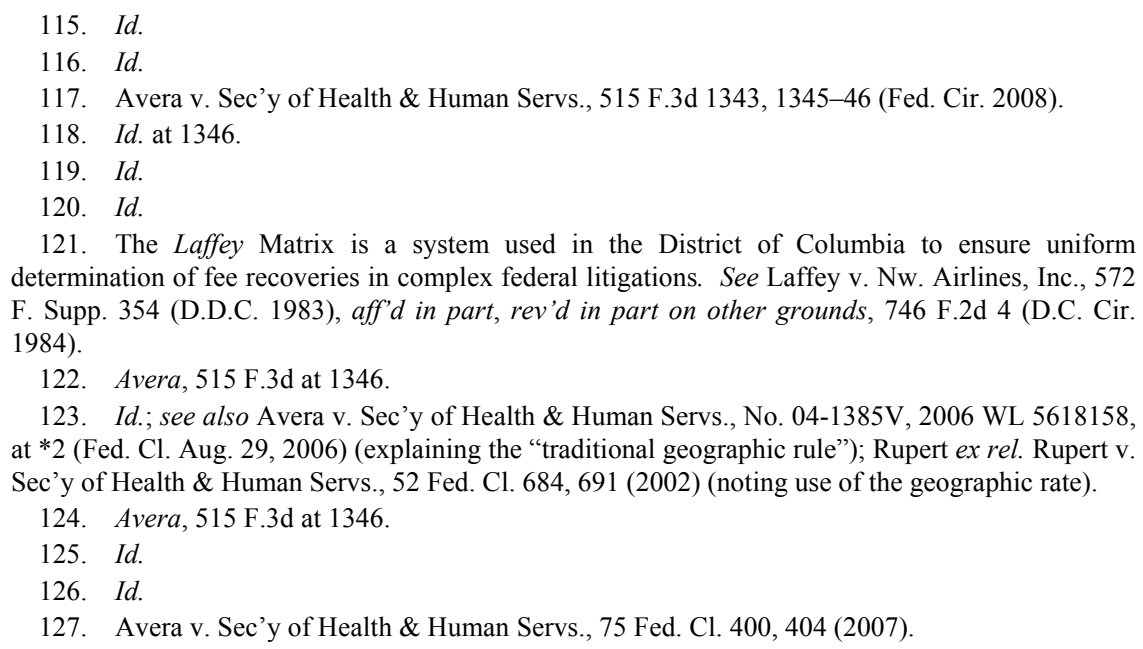


fees" in particular, the court held that "such relief is not authorized by the Vaccine Act." 128 The Averas appealed to the Federal Circuit. ${ }^{129}$

The first (and primary) issue before the court on appeal was which forum rates were appropriate, Cheyenne or Washington, D.C. ${ }^{130}$ The Federal Circuit held that Cheyenne was the appropriate forum because, inter alia, that was where the attorneys performed the entirety of their work. ${ }^{131}$ The second (and more important) issue, as framed by the court, was "whether the appellants are entitled to an award of interim fees pending appeal." "132 The government agreed with both the special master and the Court of Federal Claims that the Act made no room for "interim fees." 133

The Federal Circuit first noted that the argument that attorneys' fees were a part of "compensation" under the Act was "rejected" by Saunders v. Secretary of Health \& Human Services. ${ }^{134}$ In Saunders, the petitioner lost her merit injury claim. ${ }^{135}$ Instead of accepting the court's judgment, she elected to file a civil suit pursuant to 42 U.S.C. $\S 300 \mathrm{aa}-21(\mathrm{a}) .^{136}$ After making that election, she nevertheless sought an award of attorneys' fees. ${ }^{137}$ The government opposed that award on the basis that, because she had rejected the court's judgment under the Act, she was precluded from receiving attorneys' fees. ${ }^{138}$ The Federal Circuit ultimately rejected that argument and held that compensation under the Act was not connected to the payment of attorneys' fees under the Act. ${ }^{139}$

Using Saunders for the proposition that attorneys' fees are not tied to "compensation" under the Act, therefore, the Federal Circuit in Avera held that "[t]here is nothing in the Vaccine Act that prohibits the award of interim fees." 140 The court then looked to other fee-shifting statutes

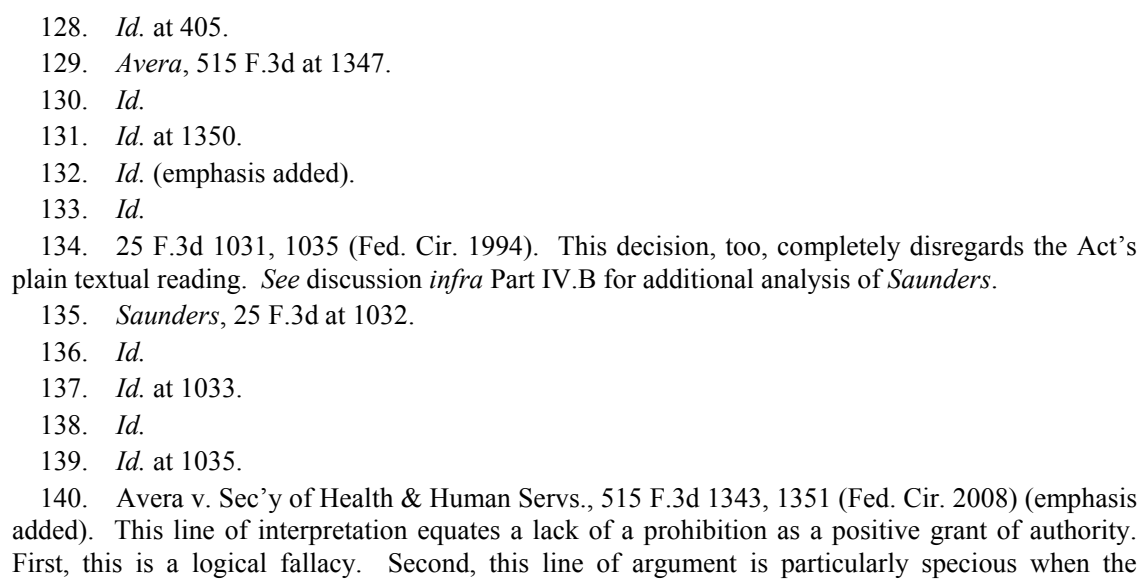


for additional support. ${ }^{141}$ First, the court examined Bradley v. School Board of Richmond, where the Supreme Court construed section 718 of Title VII of the Emergency School Aid Act. ${ }^{142}$ That section provided that "[the] court, in its discretion ... may allow the prevailing party ... a reasonable attorney's fee...."143 The Supreme Court held such language to allow an award of "interim fees" because the failure to do so would "work substantial hardship on plaintiffs and their counsel, and discourage the institution of actions despite the clear congressional intent to the contrary ...." ${ }^{144}$ The Federal Circuit then looked to Hanrahan $v$. Hampton, ${ }^{145}$ in which the Supreme Court construed 42 U.S.C. $\S 1988$ to allow the award of interim fees. ${ }^{146}$ Because of these cases - in which the Supreme Court held that other fee-shifting statutes allow interim feesand because the Act does not have a strict prevailing party standard (unlike other fee-shifting statutes), the Federal Circuit held that "interim fees" are permissible under the Act. ${ }^{147}$

Before moving on, it is hugely important to articulate carefully exactly what "interim" meant in Avera. The Avera fees were "interim" only in the sense that the merit decision was pending appeal-but there was still an initial merit decision by the special master. ${ }^{148}$ While even this definition of "interim" is at odds with the Act, it was unfortunately enlarged by subsequent decisions, namely Shaw v. Secretary of Health \& Human Services. ${ }^{149}$

\section{Shaw v. Secretary of Health \& Human Services}

In Shaw v. Secretary of Health \& Human Services, the petitioner requested "interim" attorneys' fees before the merit decision on compensation had even been issued. ${ }^{150}$ In 2001, Mr. Shaw filed a

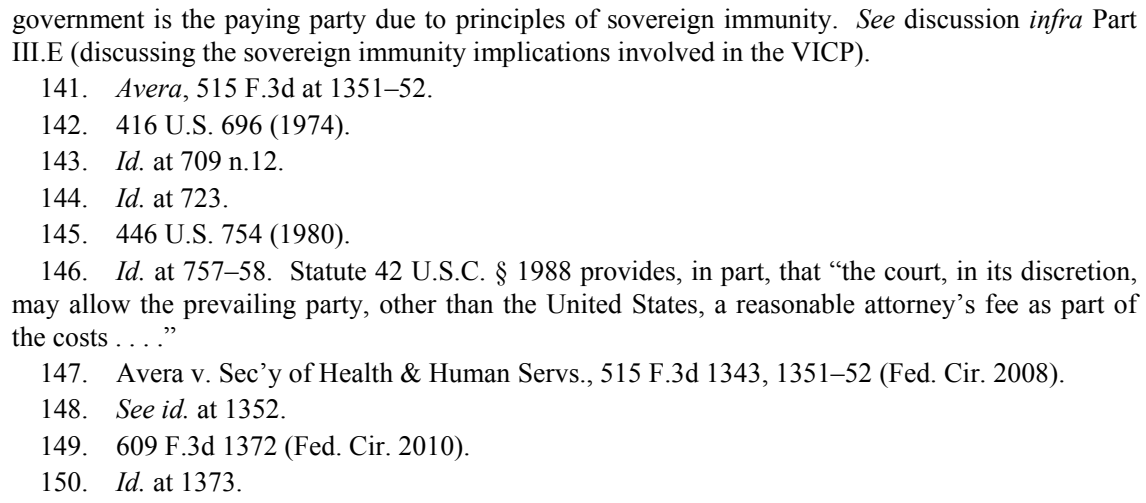


petition under the Act, claiming "that he suffered an inflammatory polyneuropathy as a result of the hepatitis B vaccine."151 Mr. Shaw's case, however, was not the only one alleging an injury related to this particular vaccine. ${ }^{152}$ Consequently, his case was stayed, pending the resolution of an omnibus proceeding involving many hepatitis B claims. ${ }^{153}$ Five years later, in 2006, the stay was lifted on Shaw's case. ${ }^{154}$

After the stay was lifted, the special master conducted a merit hearing; three witnesses, including an expert, testified. ${ }^{155}$ After that hearing, but before the special master issued his decision on compensation, Shaw submitted an "Application for Interim Fees and Costs" for $\$ 142,778.50$ in attorneys' fees and $\$ 32,311.45$ in costs. ${ }^{156}$ The government argued that many of the dollar amounts were excessive and unreasonable; consequently, the special master awarded Shaw the undisputed portion of his request. ${ }^{157}$ With regard to the disputed portion, however, the special master stated that he would revisit the amounts when a "final petition for fees and costs is submitted." 158

Mr. Shaw was not content with that answer, however, and sought review with the Court of Federal Claims. ${ }^{159}$ The Court of Federal Claims ruled that it did not have jurisdiction to review an interim decision on attorneys' fees. ${ }^{160}$ The court's rationale was that, because there had not been a final decision on the merits of the petition, there was no jurisdiction under 42 U.S.C. $§ 300 a a-12 .{ }^{161}$ In other words, the Vaccine Act did not allow for interlocutory review of orders. ${ }^{162}$ On appeal, the Federal Circuit disagreed.

\footnotetext{
151. Id. "Polyneuropathy" refers to "[a] disease process involving a number of peripheral nerves." STEDMAN's MEDICAL DICTIONARY, supra note 27, at 1404.

152. See Shaw, 609 F.3d at 1373.

153. Id.

154. Id

155. Id.

156. Id.; see also Shaw v. Sec'y of Health \& Human Servs., No. 01-707V, 2009 WL 1010058, at $* 1$ (Fed. Cl. Spec. Mstr. Mar. 27, 2009).

157. Shaw, 609 F.3d at 1373 (quoting Shaw, 2009 WL 1010058, at *2-3).

158. Id. (quoting Shaw, 2009 WL 1010058, at*3).

159. Id. at 1374 .

160. Shaw v. Sec'y of Health \& Human Servs., 88 Fed. Cl. 463, 466 (2009), rev'd, 609 F.3d 1372 (Fed. Cir. 2010).

161. Id. at 465 .

162. See, e.g., Widdoss v. Sec'y of Health \& Human Servs., 989 F.2d 1170, 1175-76 (Fed. Cir. 1993); Weiss v. Sec'y of Health \& Human Servs., 59 Fed. Cl. 624, 627 (2004); Lemire v. Sec'y of Health \& Human Servs., 60 Fed. Cl. 75, 79-80 (2004); Spratling v. Sec'y of Health \& Human Servs., 37 Fed. Cl. 202, 203-04 (1997).
} 
The Federal Circuit held that the special master's granting or denying of interim attorneys' fees is a "decision on compensation" and is thus reviewable. ${ }^{163}$ For its authority, the court cited 42 U.S.C. $§ 300$ aa12 , which includes in the statutory definition of "compensation" an amount for attorneys' fees and costs. ${ }^{164}$ The court then explained that "the Vaccine Act uses the term compensation to refer both to compensatory damages (such as payment for injury) and attorneys' fees and costs." 165 The court held therefore that a decision on pre-meritdecision interim fees is a decision on "compensation" and is thus reviewable by the Court of Federal Claims without any merit decision. ${ }^{166}$

\section{E. The "Standard" Used to Grant Pre-Merit-Decision Interim Fees}

Now that Avera and Shaw, construed together, allow for the granting of pre-merit-decision interim fees, the hotly litigated issue (and the second major problem with the VICP's current practice) has become the standard that should be used in determining whether to grant pre-meritdecision interim fees in a particular case. Naturally, if a petition is successful, attorneys' fees and costs are automatically included in the award by statute. If, however, the petitioner is not successful, the special master may award fees if the petition "was brought in good faith and there was a reasonable basis for the claim ...."167 The reasonable basis and good faith standard, not surprisingly, has been adopted as the interim fee standard. ${ }^{168}$ In practice, though, this standard has not been a real standard at all-based on the case law, there appears to be a de facto granting of pre-merit-decision interim fees. ${ }^{169}$

163. Shaw, 609 F.3d at 1376 (emphasis added). Note how the Federal Circuit fails to reconcile this with its rationale in Avera that attorneys' fees are not compensation for purposes of timing but are compensation for purposes of appellate review.

164. Id. at 1375 .

165. Id.

166. Id. at 1376. As discussed infra Part IV.A, however, Shaw completely ignores the surrounding statutory text and the operation of the Act as a whole.

167. 42 U.S.C. § 300aa-15(e)(1) (2012).

168. See, e.g., McKellar v. Sec'y of Health \& Human Servs., 101 Fed. Cl. 297, 301 (2011) (stating that a showing of good faith and reasonable basis are necessary but not sufficient for an interim fee award).

169. See, e.g., McKellar v. Sec'y of Health \& Human Servs., No. 09-841V, 2011 WL 3425606, at *2 (Fed. Cl. Spec. Mstr. June 3, 2011) ("Traditionally, special masters have been 'quite generous in finding a reasonable basis for petitioners." (quoting Turner v. Sec'y of Health \& Human Servs., No. 99-544V, 2007 WL 4410030, at*8 (Fed. Cl. Spec. Mstr. Nov. 30, 2007), rev'd, $101 \mathrm{Fed}$. Cl. 297 (2011))). In fairness, there are cases where the special master has denied interim fees, both in the pre- and post-merit context. This can happen for three reasons. First, the case did not have a 
This has caused tension between the Office of Special Masters and the Court of Federal Claims judges, as there is divergence in both levels of the court. A prime case typifying this problem is McKellar $v$. Secretary of Health \& Human Services. ${ }^{10}$

In McKellar, the petitioner alleged that the human papillomavirus (HPV) and menactra, varicella, tetanus-diphteria-acellular-pertussis (Tdap) vaccines caused fever, difficulty swallowing, oral blisters, and other miscellaneous maladies. ${ }^{171}$ Petitioner's counsel compiled 400 pages of medical records. ${ }^{172}$ Although the underlying merit decision had not been reached, counsel submitted an application for interim attorneys' fees for roughly $\$ 18,000 .{ }^{173}$ After submitting the fee application, counsel notified the special master that he would be withdrawing as counsel of record, and thus labeled the fee requests as "final" requests. ${ }^{174}$ In sum, there had been no decision on the merits, but counsel wanted out and wanted to be paid first.

Citing Avera and using the standard of good faith and reasonable basis, the special master granted the fees ${ }^{175}$ - despite the fact that the special master expressly stated in her opinion that, "Petitioner's medical records disclosed no evidence of a valid claim for compensation . . .."176 To find good faith, the special master held that good faith is generally presumed. ${ }^{177}$ Moreover, according to the special master, this good faith inquiry is subjective in nature. ${ }^{178}$

Regarding the reasonable basis element, the special master noted that traditionally special masters have been "quite generous in finding a

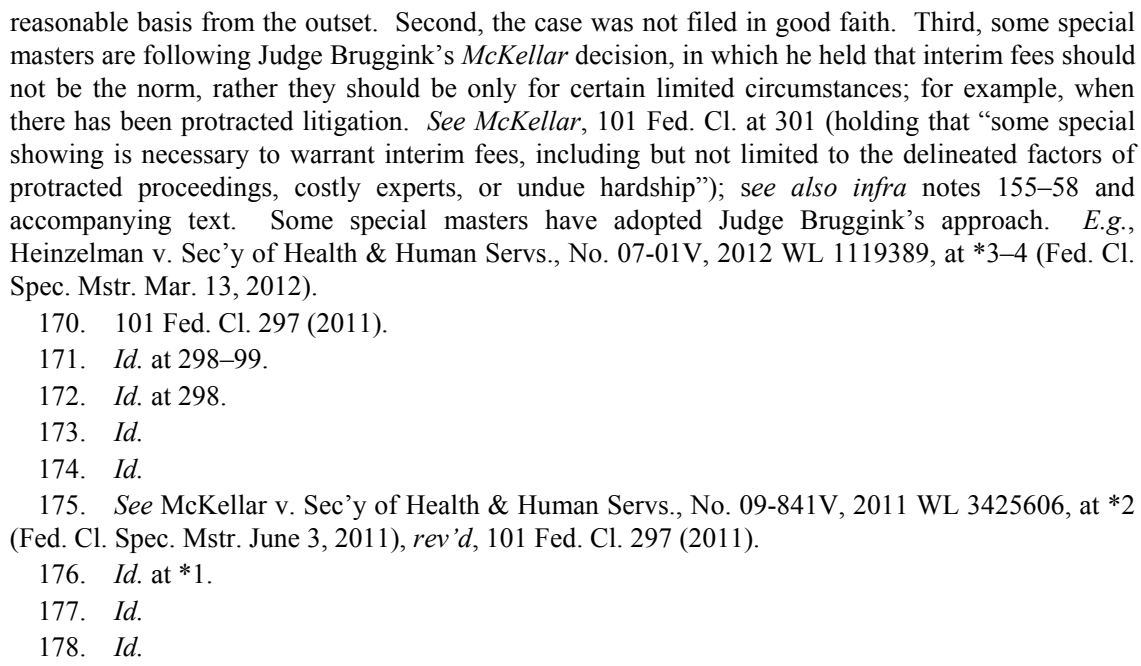
masters are following Judge Bruggink's McKellar decision, in which he held that interim fees should not be the norm, rather they should be only for certain limited circumstances; for example, when there has been protracted litigation. See McKellar, 101 Fed. Cl. at 301 (holding that "some special showing is necessary to warrant interim fees, including but not limited to the delineated factors of protracted proceedings, costly experts, or undue hardship"); see also infra notes 155-58 and accompanying text. Some special masters have adopted Judge Bruggink's approach. E.g., Heinzelman v. Sec'y of Health \& Human Servs., No. 07-01V, 2012 WL 1119389, at *3-4 (Fed. Cl. Spec. Mstr. Mar. 13, 2012).

170. 101 Fed. Cl. 297 (2011).

171. Id. at 298-99.

172. Id. at 298 .

173. Id

174. Id

175. See McKellar v. Sec'y of Health \& Human Servs., No. 09-841V, 2011 WL 3425606, at *2

(Fed. Cl. Spec. Mstr. June 3, 2011), rev'd, 101 Fed. Cl. 297 (2011).

176. Id. at $* 1$

177. Id.

178. Id 
reasonable basis for petitioners." "179 Even though the special master noted that not all the medical records had been collected, and even though " $[t]$ he citations to the medical records may have been incomplete and taken out of context," the special master still held that there was a reasonable basis to file the petition. ${ }^{180}$ This is despite the fact that the only evidence of any vaccine injury was the patient's own statement to her doctor to the effect that the vaccine caused the blisters and an anonymous VAERS report, ${ }^{181}$ which could have also been filed by the petitioner. Basically, the only evidence consisted of self-serving statements made by the petitioner. Nevertheless, the special master cut the withdrawing counsel a check. ${ }^{182}$

What we can draw from this is that attorneys' fees and costs are almost a sure thing in many cases, even though most cases go on to be

179. Id. at *2 (quoting Turner v. Sec'y of Health \& Human Servs., No. 99-544V, 2007 WL 4410030, *8 (Fed. Cl. Spec. Mstr. Nov. 30, 2007)).

180. Id. at*3. Fortunately, Judge Bruggink, upon review, reversed this decision of the special master on the grounds that the special master conflated the tests of good faith and reasonable basis. McKellar v. Sec'y of Health \& Human Servs., 101 Fed. Cl. 297, 305 (2011). But, the decision of the special master is nevertheless illustrative of the problems with the current interpretation of the Act. The current trend is to equivocate "reasonable basis" with meaning "not frivolous." See, e.g., Perreira v. Sec'y of Health \& Human Servs., 27 Fed. Cl. 29, 35 (1992). Other commentators have lamented at this all too flexible standard. E.g., Boxler, supra note 12, at 20-22 (discussing the subjective and low hurdle of good faith and easily satisfied reasonable basis elements). On remand - even after Judge Bruggink's first McKellar opinion-the special master still awarded attorneys' fees and costs. McKellar v. Sec'y of Health \& Human Servs., No. 09-841V, 2012 WL 362030 (Fed. Cl. Spec. Mstr. Jan. 13, 2012), rev'd, 2012 WL 1884703 (Fed. Cl. May 3, 2012). On review, yet again, Judge Bruggink held as a matter of law that interim fees were not appropriate. See McKellar v. Sec'y of Health \& Human Servs., No. 09-841V, 2012 WL 1884703 (Fed. Cl. May 3, 2012). The multiple iterations of back and forth in McKellar on interim fees is entirely representative of the problem that pre-merit-decision interim fees and the associated moral hazard problem is clogging the Court of Federal Claims' docket.

181. "The Vaccine Adverse Event Reporting System (VAERS) is a national vaccine safety surveillance program co-sponsored by the Centers for Disease Control and Prevention (CDC) and the Food and Drug Administration (FDA)." Vaccine Adverse Event Reporting System (VAERS), U.S. DeP'T OF HEAlth \& HuMAN SERVS., http://vaers.hhs.gov/index (last visited Oct. 28, 2014). Anybody can file a VAERS report, and "VAERS seeks reports of any clinically significant medical event that occurs after vaccination, even if the reporter cannot be certain that the event was caused by the vaccine." VAERS Frequently Asked Questions, U.S. DEP'T OF HEALTH \& HuMAN SERVS., http://vaers.hhs.gov/about/faqs (last visited Oct. 28, 2014). As Judge Bruggink noted, "[w]hile VAERS data may be useful to scientific researchers, the purpose of a VAERS report is not to establish causal connection, or any connection for that matter, between a vaccine and subsequent maladies." McKellar v. Sec'y of Health \& Human Servs., 101 Fed. Cl. 297, 304 (2011). The Court of Federal Claims has been reluctant to rely on such reports. See id. at 304; see also Ryman v. Sec'y of Health \& Human Servs., 65 Fed. Cl. 35, 39-40 (2005); Capizzano v. Sec'y of Health \& Human Servs., 63 Fed. Cl. 227, 231 (2004), vacated on other grounds, 440 F.3d 1317 (Fed. Cir. 2006); Manville v. Sec'y of Health \& Human Servs., 63 Fed. Cl. 482, 494 (2004).

182. See supra note 181 (noting Judge Bruggink's reversal of the special master). 
dismissed. ${ }^{183}$ Under the current state of the VICP, it seems that for there not to be good faith or a reasonable basis, there must be actual knowledge that the claim is frivolous. ${ }^{184}$ For example, in Perreira $v$. Secretary of Health \& Human Services, the special master used a "patently unreasonable" standard in adjudging the attorneys' fees award. ${ }^{185}$ In Grice v. Secretary of Health \& Human Services, the court required a showing of "direct evidence of bad faith ...."186 In Jessen $v$. Secretary of Health \& Human Services, the special master expressly declined to adopt a "very strict" interpretation of reasonable basis and instead noted that attorneys" fees and costs are denied "[i]n situations where truly there existed no logical basis for the claim ...."187 There have even been attorneys' fees awards when the petition did not include specific vaccination records. ${ }^{188}$ In sum, the standard has become far too lawyer-friendly.

\section{BEDROCK PRINCIPLES AND CANONS OF STATUTORY INTERPRETATION PRECLUDE AN AWARD OF PRE-MERIT-DECISION INTERIM FEES}

The solution to the problem is a simple one: proper statutory construction. The statute, properly construed, does not allow for any award of fees or costs before a decision on the underlying merits. Ultimately, this is a question of how the Act defines the term "compensation," what that term includes, and when compensation is available for a petitioner. While courts have not favored this result as a matter of policy, it is not within the jurisdiction of any court to make vaccine policy from the bench. The court's job-in fact, its duty-is to

183. VICP Statistics, supra note 79. For example, in fiscal year 2011, 261 petitions were paid merit compensation, while 1,371 were dismissed. Id. In fiscal year 2012, 260 petitions were paid merit compensation, while 2,439 petitions were dismissed. Id. While cases are not normally adjudicated in the same fiscal year as they were filed, these numbers nevertheless show that more petitions are dismissed in any year than paid merit compensation.

184. This is bolstered by the special master's decision which noted that the Secretary, in opposition, did not "[present] any facts that addressed the state of mind of the Petitioner." McKellar v. Sec'y of Health \& Human Servs., No. 09-841V, 2011 WL 3425606 at *1 (Fed. Cl. Spec. Mstr. June 3, 2011).

185. No. 90-847V, 1992 WL 164436, at*3 (Fed. Cl. Spec. Mstr. June 12, 1992).

186. 36 Fed. Cl. 114, 121 (1996)

187. No. 94-1029V, 1997 WL 48940, at*1, *5 (Fed. Cl. Spec. Mstr. Jan. 17, 1997).

188. See Melbourne v. Sec'y of Health \& Human Servs., No. 99-694V, 2007 WL 2020084 (Fed. Cl. Spec. Mstr. June 25, 2007). But see Brown ex rel. Brown v. Sec'y of Health \& Human Servs., No. 99-539, 2005 WL 1026713, at *2-3 (Fed. Cl. Spec. Mstr. Mar. 11, 2005). 
interpret the plain language of the text. If Congress does not like that result, insofar as it affects the efficacy of the VICP, Congress alone has the constitutional authority to change the Act.

The goal of any jurist, in construing a statute, is to "[give] effect to the text that the lawmakers have adopted."189 According to Holmes, a judge "[does] not inquire what the legislature meant; we ask only what the statute means." ${ }^{190}$ As deftly stated by Justice Marshall:

[T] he intention of the instrument must prevail; that this intention must be collected from its words; that its words are to be understood in that sense in which they are generally used by those for whom the instrument was intended; that its provisions are neither to be restricted into insignificance, nor extended to objects not comprehended in them, nor contemplated by its framers ....

Consequently, Anglo-American law has developed principles of interpretation that seek to guide the interpreter to a fair reading of the text. ${ }^{192}$ By using these principles, the current problematic interim fee debacle would have been avoided.

\section{A. Supremacy of Text and the Whole-Text Canon}

Broadly speaking, the most fundamental principle that is lacking in interim fee jurisprudence is the supremacy of text principle. ${ }^{193}$ This principle provides that " $[\mathrm{t}]$ he words of a governing text are of paramount concern, and what they convey, in their context, is what the text means." 194 This tradition is found in antiquity; as Justinian phrased it, "A verbis legis non est recedendum," or "Do not depart from the words of the law." 195 This principle can be found in many opinions, expressed by

189. See Antonin Scalia \& Bryan A. Garner, Reading Law: The Interpretation of LEGAL TEXTS 29 (2012).

190. Oliver Wendell Holmes, The Theory of Legal Interpretation, 12 HARV. L. REV. 417, 419 (1899).

191. Ogden v. Saunders, 25 U.S. 213, 332 (1827) (Marshall, C.J., dissenting) (emphasis added).

192. See, e.g., SCALIA \& GARNER, supra note 189, at xxvii. By "fair reading," Scalia and Garner advance "determining the application of a governing text to given facts on the basis of how a reasonable reader, fully competent in the language, would have understood the text at the time it was issued." Id. at 33.

193. See id. at 56.

194. Id

195. Id.; see also State ex rel. Dowling v. Butts, 149 So. 746, 757 (Fla. 1933) (““[T]hat they ought not to make any construction against the express letter of the statute; for nothing can so express the meaning of the makers of the act as their own direct words, for "index animi sermo." 
the words, "If the language is clear and unambiguous, judicial inquiry is at an end in all but the most extraordinary circumstances, and the court must give effect to the clear meaning of the statute as written." 196

Seeking to effectuate this principle, courts have adopted canons to aid in the interpretive process. The first canon applicable here is the "whole-text canon." 197 As the name implies, this principle provides simply that the text (here, the Act) must be construed as a whole. As stated by Justice Kennedy, "In ascertaining the plain meaning of [a] statute, the court must look to the particular statutory language at issue, as well as the language and design of the statute as a whole."198

This canon includes more than just considering every word of a statute; it requires the court to consider the text "in view of its structure and of the physical and logical relation of its many parts."199 As Sir Edward Coke wrote, "[I]t is the most natural and genuine exposition of a statute to construe one part of the statute by another part of the same statute, for that best expresseth the meaning of the makers."200

The text, organization, and structure of the Vaccine Act preclude an interpretation that allows pre-merit-decision interim fees. The problem with Avera, Shaw, and their progeny is that they treat the word

And it would be dangerous to give scope to make a construction in any case against the express words, when the meaning of the makers doth not appear to the contrary, and when no inconvenience will thereupon follow; and therefore in such cases 'a verbis legis non est recedendum."') (Ellis, J., concurring) (quoting Edrich's Case, (1907) 77 Eng. Rep. 238 (K.B.) 239; 5 Co. Rep. 118a, 118b); Macon \& A.R. Co. v. Macon \& D.R. Co., 13 S.E. 157, 158 (Ga. 1890) ("The words are to receive their plain and obvious import; and we think the maxim a verbis legis non est recedendum, applies in this case.").

196. Quiles Rodriguez v. Calderon, 172 F. Supp. 2d 334, 339 (D.P.R. 2001); see also Estate of Cowart v. Nicklos Drilling Co., 505 U.S. 469, 476 (1992) ("The controlling principle in this case is the basic and unexceptional rule that courts must give effect to the clear meaning of statutes as written."); Ernst \& Ernst v. Hochfelder, 425 U.S. 185, 201 (1976) ("When the Court finds the statutory language to be unambiguous, its clear meaning is controlling and the Court does not need to refer to any other source to interpret its meaning.").

197. See SCALIA \& GARNER, supra note 189 , at 167

198. K Mart Corp. v. Cartier, Inc., 486 U.S. 281, 291 (1988); see also Bethesda Hosp. Ass'n v. Bowen, 485 U.S. 399 (1988) (examining the "language and design of the statute as a whole"); Offshore Logistics, Inc. v. Tallentire, 477 U.S. 207, 221 (1986) (evaluating a statute "in light of the language of the Act as a whole"); Mastro Plastics Corp. v. NLRB, 350 U.S. 270, 285 (1956) ("“In expounding a statute, we must not be guided by a single sentence or member of a sentence, but look to the provisions of the whole law, and to its object and policy." (quoting United States v. Heirs of Boisdoré, 49 U.S. 113, 122 (1849))).

199. SCALIA \& GARNER, supra note 189 , at 167 . Moreover, Coke also noted that, "If any section [of a law] be intricate, obscure, or doubtful, the proper mode of discovering its true meaning is by comparing it with other sections, and finding out the sense of one clause by the words or obvious intent of the other." Id. at 167 n.2.

200. Id. at $167 \mathrm{n} .1$. 
"compensation" myopically, failing to see the interrelatedness of the phrase "compensation" as used elsewhere in the Act. The term "compensation" is used many times in the Act, and the whole-text canon dictates that we must consider how the word "compensation" is used throughout the Act as a whole. Section 11 of the Act provides that a proceeding for "compensation" is commenced by serving a petition with the Court of Federal Claims. ${ }^{201}$ Section 13 provides that "compensation" shall be awarded under the VICP if certain requirements are satisfied. ${ }^{202}$ Finally, $\S 15$ defines what constitutes "compensation" under the Act. ${ }^{203}$ We must examine how these provisions work together.

Under $\S 15$, there are two ways-and two ways only-that compensation can be paid: (1) if the petitioner is successful on the merits and $\S 15(\mathrm{a})$ therefore operates to pay the statutory components of "compensation," including attorneys' fees, or (2) if the petitioner is not successful on the merits, thereby triggering the discretionary payment of "compensation" under $\S 15(\mathrm{e})(1)(\mathrm{B})$ if the petition was brought in good faith and possessed a reasonable basis. ${ }^{204}$

Let's examine the actual language contained in $\S 15(\mathrm{e})(1)(\mathrm{B})$ :

If the judgment of the United States Court of Federal Claims on such a petition does not award compensation, the special master or court may award an amount of compensation to cover petitioner's reasonable attorneys' fees and other costs incurred in any proceeding on such petition if the special master or court determines that the petition was brought in good faith and there was a reasonable basis for the claim for which the petition was brought.

Plainly, the payment of compensation, including attorneys' fees, in an unsuccessful petition is purely discretionary. Although courts agree on this, they have radically and intentionally departed from the text on the required triggering condition that allows the court to make that discretionary decision on interim fees.

Examining the plain text of the statute - and how the statute as a whole operates - the answer should be evident: it requires a merit decision on the petition. Supporting this conclusion is the use of the word "judgment" and the phrase "judgment ... on such a petition does

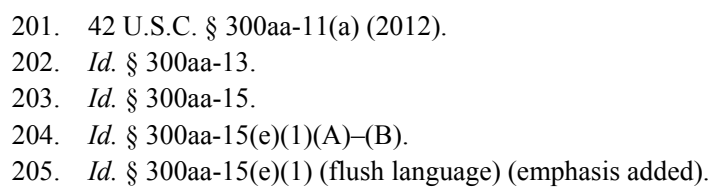


not award compensation." 206 The term "judgment" is used other places in the Act. Section 12, which concerns the court's jurisdiction over petitions, is the operating section regarding "judgments" entered in the VICP. Section 12(e)(3) provides how and when a "judgment" is entered with respect to a petition. ${ }^{207} \mathrm{~A}$ judgment is entered if a party does not request a motion for review of the special master's decision, or if such a motion is filed and the court sustains the special master's decision. ${ }^{208}$ Both situations contemplate a decision on the merits of compensation. In sum, there can be no judgment and therefore no "compensation" awarded until an actual judicial determination has been made regarding the petition's merits.

This conclusion is bolstered further by the next phrase in $\S$ 15(e)(1)(B), "on such a petition does not award compensation." The phrase is modifying the term "judgment." The whole structure of the Act, moreover, is directed at the Court of Federal Claims to issue a decision (read: judgment) on the petition regarding compensation. Without this critical decision regarding compensation (i.e., the judgment), the discretionary aspect of compensation-including attorneys' fees and costs - is never triggered statutorily. Failing to see how compensation is tied to the other sections abandons the whole-text canon.

In addition, this interpretation also comports with congressional intent. In 1989, the Act was amended. ${ }^{209}$ The amendments changed the exact source of the confusion here, i.e., $\S 15(\mathrm{e})(1)$. The stated purpose of the amendments was "to clarify that the special master's or Claims Court award for amounts to cover attorney's fees and costs is to be included after proceedings are complete." 210 The statute's text and the legislative history are abundantly clear.

206. Id. (emphasis added).

207. Id. $\S 300 a a-12(\mathrm{e})(3)$, in full, states: "In the absence of a motion under paragraph (1) respecting the special master's decision or if the United States Court of Federal Claims takes the action described in paragraph (2)(A) with respect to the special master's decision, the clerk of the United States Court of Federal Claims shall immediately enter judgment in accordance with the special master's decision."

208. Id.

209. See Omnibus Budget Reconciliation Act of 1989, Pub. L. No. 101-239, 103 Stat. 2106 (1989).

210. H.R. REP. NO. 101-386, at 517 (1989) (Conf. Rep.), reprinted in 1989 U.S.C.C.A.N 3018, 3120. 


\section{B. Definitional Sections Are to Be Carefully Followed and Used Consistently}

Statutes often contain discrete definition sections, ${ }^{211}$ or specifically define terms in a particular subsection for use in that subsection. ${ }^{212}$ Definition sections can also be used to give an artificial or special meaning to a word that already has an ordinary, commonly accepted meaning. ${ }^{213}$ Section 15 of the Vaccine Act does exactly that: it gives a specific meaning to the word "compensation" as used throughout the Act. Section 15 of the Act provides that "compensation" awarded under the VICP "shall include" a statutory list of damages, including unreimbursed expenses, diminished loss of earnings, pain and suffering, and, if a death resulted, a death payout. ${ }^{214}$ It is within this statutory definition of compensation - and in this section only - that fee shifting is involved. In other words, attorneys' fees are tied directly to the term "compensation" under the Act. In fact, the attorneys' fees in a successful merits case "shall also [be awarded] as part of such compensation." 215 Attorneys' fees under the Act are therefore inextricably tied and related to compensation. Under the transitive principle, therefore, any condition precedent to compensation awarded under the Act must also be a condition precedent to any payment of attorneys' fees or costs. ${ }^{216}$ The current interpretation of the Act, however, completely disregards the transitive nature and definitional use of "compensation" in the Act.

The Federal Circuit had occasion to discuss the operation of $\S 15$ and compensation in Saunders v. Secretary of Health \& Human Services. ${ }^{217}$ In Saunders, the petitioner alleged that her son suffered permanently from seizures due to the DPT vaccine her son received. ${ }^{218}$ The special master denied compensation and held that the petitioner failed to show

211. E.g., 11 U.S.C. $\S 101$ (2012) (defining bankruptcy terms).

212. This practice is common in the Internal Revenue Code. See, e.g., 26 U.S.C. § 117(b)(1) (2012) (defining "qualified scholarship").

213. SCALIA \& GARNER, supra note 189 , at 225.

214. 42 U.S.C. $\S 300 \mathrm{aa}-15$ (2012); see also supra Part II.B. (expounding upon the types of compensation payouts under the Act).

215. Id. § 300aa-15(e) (emphasis added).

216. The transitive principle is a mathematical and logical rule that provides if $\mathrm{A}$ bears some relation to $\mathrm{B}$, and $\mathrm{B}$ bears that same relation to $\mathrm{C}$, then $\mathrm{A}$ bears it to $\mathrm{C}$. In mathematical terms, if $\mathrm{A}=$ $\mathrm{B}$, and $\mathrm{B}=\mathrm{C}$, then $\mathrm{A}=\mathrm{C}$. See, e.g., Derek Haylock \& Fiona Thangata, Key Concepts IN TEACHING PRIMARY MATHEMATICS 173 (2007).

217. 25 F.3d 1031 (Fed. Cir. 1994).

218. Id. at 1032 . 
by a preponderance of the evidence that the DPT vaccine was the cause in fact. ${ }^{219}$ Petitioner did not seek review in the Court of Federal Claims and the court therefore entered judgment and dismissed the petition. ${ }^{220}$

Four months after the judgment and dismissal, petitioner sought a payment of attorneys' fees and costs under $\S 15$, which allows payment of fees and costs even if merit compensation is not awarded. ${ }^{221}$ The government opposed the application, arguing that the award was prohibited as a matter of law because the petitioner rejected the court's judgment, ${ }^{222}$ which, according to the government, precluded any subsequent judgment awarding attorneys' fees. The special master, over the government's objection, awarded fees and costs in part. ${ }^{223}$

On review at the Court of Federal Claims, the government argued that the election contained in $\S 21$ is an "acceptance or rejection of all the compensation, including attorneys' fees and costs, to which a claimant might be found entitled under the Act." ${ }^{224}$ Also pointing to $\S 15$, the government argued that compensation includes attorneys' fees and costs. $^{225}$ Thus, when taken together, any payment of compensation (i.e., attorneys' fees) is not allowed after an election has been formally made to reject the merit judgment compensation. ${ }^{226}$ The court noted that the government's argument "has the force of plain language behind it."227 Nevertheless, the court ultimately affirmed the special master's award. ${ }^{228}$ It held that $\S 15(\mathrm{e})(1)$ "is most reasonably read as permitting all allowable elements of compensation to be addressed in a single award rather than as requiring all such elements to be addressed in a single award." 229 The government appealed to the Federal Circuit.

On appeal, the issue was the operation of $\S 15(\mathrm{f})(1)$, which provides, in part, "no compensation may be paid until an election has been made,

219. Id.; see also Saunders v. Sec'y of Health \& Human Servs., No. 90-826V, 1992 WL 700268 (Fed. Cl. Spec. Mstr. May 26, 1992).

220. Saunders, 25 F.3d at 1032.

221. Id. at 1033 .

222. Id.

223. Id. The special master did not award fees for petitioner's expert witness due to lack of substantiating documentation. See Saunders v. Sec'y of Health \& Human Servs., 26 Cl. Ct. 1221, 1223 (1992).

224. Saunders, $26 \mathrm{Cl}$. Ct. at 1223.

225. Id. at 1224 .

226. Id.

227. Id

228. Id. at 1227.

229. Id. at 1225 . 
or has been deemed to have been made, under [§ 21(a)] of this title to receive compensation." 230 Section 21(a) provides that after judgment has been entered by the court, the petitioner must elect one of two options. ${ }^{231}$ The first option, which applies only if compensation was awarded, is an election to receive the compensation or to file a civil action for damages. ${ }^{232}$ The second option, if the judgment did not award compensation, is an election to accept the judgment or to file a civil action for damages. ${ }^{233}$ Therefore, under both options the petitioner must choose whether he or she will accept the judgment of the court or will proceed with a civil action in a different court. If the petitioner does not file the written election, the statute deems the petitioner to have elected to accept the judgment of the court (thereby barring a subsequent civil suit). ${ }^{234}$

The parties did not dispute that Saunders' petition was brought in good faith and had a reasonable basis. ${ }^{235}$ Rather, the government argued that unless the judgment was accepted under $\S 15(f)(1)$, no payment could be triggered under the Act. ${ }^{236}$ Similar to the argument made in this Article, the government contended that "compensation" under the Act included both merit compensation, if any, and the payment of attorneys' fees. ${ }^{237}$

In interpreting $\S 15$, the Federal Circuit stated that "the term 'compensation' is used mainly in the Vaccine Act to mean payment for expenses incurred and losses suffered as a result of the administration of a vaccine," ${ }^{238}$ and that "the primary focus of the term 'compensation' is upon payment for expenses incurred and losses suffered from the administration of a vaccine, rather than upon recovery of attorneys' fees and costs incurred in court proceedings under the [VICP]." ${ }^{239}$ Both of these statements, although true, ignore the special operation of $\S 15$ as a definition section with a transitive effect. The purpose of $\S 15$ is to define the use of the word "compensation" within the meaning of the

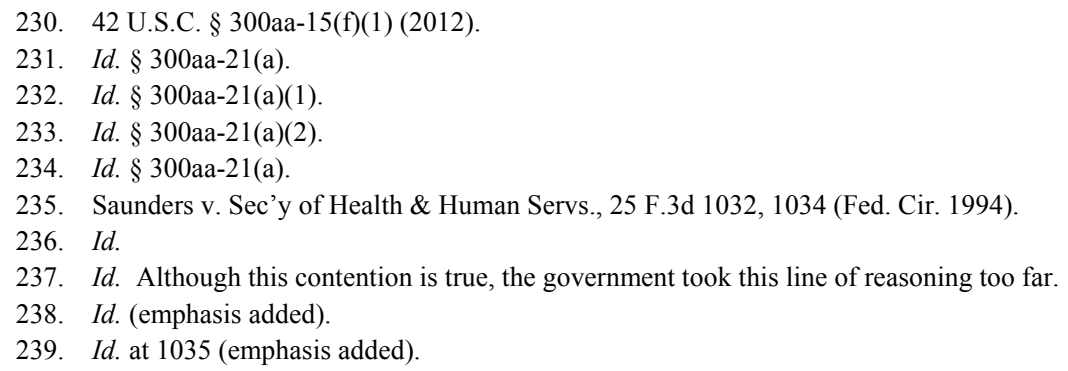


Act-i.e., to delineate what is includable in a "compensation" payment. Moreover, because the Act adds attorneys' fees to the concept of compensation, which is contrary to the "American rule" of attorneys" fees generally, ${ }^{240}$ it is even more imperative to abide by the definitional aspect of $\S 15$.

The Federal Circuit then noted the principle that it has to give meaning and effect to all provisions of the Act. ${ }^{241}$ According to the court, adopting the government's position would not accord with this principle of statutory construction because the position would result in a purported internal inconsistency. ${ }^{242}$ Under the court's reasoning, that inconsistency would be in $\S 15$, which notes that if the special master does not award compensation, it can award an amount of compensation to cover attorneys' fees and costs. ${ }^{243}$ Presumably, the court is referring to the perceived conflict when a court will not award compensation with one hand, and yet will with the other hand. To reconcile this perceived "conflict," the two "compensation" terms in the different sections, according to the court, must be referring to two different things - one is merit compensation and the other is attorneys' fees and costs. ${ }^{244}$ Thus, because compensation can mean two different things in $\S 15$, there's no reason why it cannot be referring to two different things in $\S 21 .{ }^{245}$ Here, the court was in the right church but wrong pew.

By holding that attorneys' fees are completely unhinged from compensation as used in $\S 15(f)(1)$ and $\S 21(a)$, they have become unhinged in all other sections of the Act, including the timing provisions, which eventually gave rise to pre-merit-decision interim fees. There is a better way to reconcile the perceived conflict, however, and that is to recognize that the term "compensation," as used in the Act, is an umbrella term that has two constituent parts: (a) compensatory damages

240. Henry F. Minnerop \& Kimberly A. Johns, Attorneys' Fees in Arbitration, 61 Bus. LaW. 589, 589-90 (2006) ("It is a long-standing principle of American law, the American Rule, that a prevailing party in a litigation is not entitled to an award of attorneys' fees except (i) where authorized by statute, (ii) where the parties have agreed that the prevailing party should be awarded attorneys' fees, or (iii) where the court concludes that one of the litigants has acted in bad faith.”); Johnny Parker, The Common Fund Doctrine: Coming of Age in the Law of Insurance Subrogation, 31 IND. L. REV. 313, 313 (1998) ("Pursuant to the 'American Rule,' each party is obligated to pay its own attorney's fees, regardless of the outcome of the litigation.").

241. Saunders, 25 F.3d at 1035.

242. Id.

243. Id.; see also 42 U.S.C. § 300aa-15(e)(1)(B) (2012).

244. Saunders, 25 F.3d at 1035.

245. Id. 
and (b) attorneys' fees and costs. Therefore, while compensatory damages and attorneys' fees are distinct, they are treated similarly with regard to other provisions of the Act. In other words, although the court does not award one type of compensation, it can still award another type (subset) of compensation, but both are still "compensation" with regard to the timing and judgment restrictions the Act applies to that term. In sum, those conditions elsewhere in the Act apply to any compensationwhether it is compensatory damages or attorneys' fees compensation. Moreover, this interpretation better accords with the text immediately surrounding the $\S 15(\mathrm{e})(1)$ block text, which refers to "the judgment" not awarding compensation (timing provision, i.e., post-merit decision).

\section{Casus Omissus Pro Omisso Habendus Est}

The canon of casus omissus pro omisso habendus est provides that a court should not add to what the text states or reasonably implies. ${ }^{246}$ As Justice Blackmun noted in construing the Securities Exchange Act, "[I]f the Congress [had] intended to provide additional exceptions, it would have done so in clear language ....,247 Justice Louis Brandeis said, similarly, "A casus omissus does not justify judicial legislation."248 As elucidated by Justice Buller:

246. SCALIA \& GARNER, supra note 189, at 93; see also Chan v. Korean Air Lines, Ltd., 490 U.S. 122, 135 (1988) ("Neither can this Court supply a casus omissus in a treaty, any more than in a law. We are to find out the intention of the parties by just rules of interpretation applied to the subject matter; and having found that, our duty is to follow it as far as it goes, and to stop where that stops - whatever may be the imperfections or difficulties which it leaves behind." (quoting In re The Amiable Isabella, 19 U.S. 1, 71 (1821))); United States ex rel. Coy v. United States, 316 U.S. 342, 345 (1942) (finding that failure of a criminal procedural rule to provide for appeals of orders from the district court was a casus omissus which left a prior rule in force); United States v. Union P. R.R., 91 U.S. 72, 86 (1875) ("I venture to lay it down as a general rule respecting the interpretation of deeds, that all latitude of construction must submit to this restriction; namely, that the words may bear the sense which by construction is put upon them. If we step beyond this line, we no longer construe men's deeds, but make deeds for them." (quoting Gibson v. Minet, (1791) 126 Eng. Rep. 326, 352; 1 H. BL. 569, 615)); Bailey v. Kain, 192 N.E.2d 486, 490-91 (Ind. Ct. App. 1963) ("That which the legislature has omitted through oversight, inadvertence or otherwise is a casus omissus and falls within the legal maxim of 'Casus Omissus Pro Omisso Habendus Est.,' (a case omitted is to be held as intentionally omitted)." (quoting TRAYNOR, LEGAL MAXIMS 67)); State v. Crenshaw, 35 So. 456, 456 (1903) (“'It was a maxim of the old law that casus omissus pro omisso habendus est, that is, that a case omitted is to be held as intentionally omitted, ... and so, not to have been omitted merely by inadvertence or accident; still the courts are not at liberty to add to the language of the law; and it must be held that the Legislature intended to omit the specific case, however that may appear in connection with the general passage of the statute." (quoting HENRY CAMPBELL BLACK, HANDBOOK ON THE CONSTRUCTION AND INTERPRETATION OF THE LAWS 57-58 (1896))).

247. Petteys v. Butler, 367 F.2d 528, 538 (8th Cir. 1966) (Blackmun, J., dissenting).

248. Ebert v. Poston, 266 U.S. 548, 554 (1925). 
We are bound ... to take the act of Parliament as they have made it: a casus omissus can in no case be supplied by a court of law, for that would be to make laws; nor can I conceive that it is our province to consider whether such a law that has been passed be tyrannical or not. $^{249}$

Under $\S 15(\mathrm{e})$, there is simply no exception to the textual requirement of a predicate merit judgment being needed to award any attorneys' fees or costs. The court cannot unilaterally carve out an exception, even with the best of intentions-and even if it would be "better" policy. To do so, in the words of Justice Brandeis, "transcends the judicial function."250

\section{Remedial Statutes Are Not to Be Liberally Construed in Contravention of the Text}

A common refrain in judicial opinions, including even those involving the Vaccine Act, ${ }^{251}$ is that "remedial" statutes are to be liberally construed. ${ }^{252}$ Because the Vaccine Act is a remedial statute (i.e., to make injured persons whole), the theory goes, it should be construed broadly and liberally. ${ }^{253}$ This rationale, in part, led to the absurdity in Shaw - contrary to the plain text of $\S 15$ - that attorneys'

249. United States v. Union P. R.R., 91 U.S. 72, 85 (1875) (quoting Jones v. Smart, (1785) 99 Eng. Rep. 963, 967; 1 T.R. 44).

250. Iselin v. United States, 270 U.S. 245, 251 (1926).

251. See, e.g., Cloer v. Sec'y of Health \& Human Servs., 675 F.3d 1358, 1362 (Fed. Cir. 2012) (en banc), aff'd sub nom. Sebelius v. Cloer, 133 S.Ct. 1886 (2013) ("Remedial legislation like the Vaccine Act should be construed in a manner that effectuates its underlying spirit and purpose."); Zatuchni ex rel. Estate of Snyder v. Sec'y of Health \& Human Servs., 73 Fed. Cl. 451, 458 (2006), aff'd sub nom. Zatuchni v. Sec'y of Health \& Human Servs., 516 F.3d 1312 (Fed. Cir. 2008) ("Where, however, jurisdictional prerequisites are satisfied, as they are in this case, the Vaccine Act ought to then be interpreted by a plain reading of its terms, mindful of the Act's remedial intent."); Rooks v. Sec'y of Health \& Human Servs., 35 Fed. Cl. 1, 8 (1996) ("By presuming that the Act only provides for direct administrative situations and, thus, excluding in utero situations, the remedial purpose of compensating vaccine-related injuries would be thwarted."); Schultz v. Sec'y of Health \& Human Servs., No. 12-234V, 2013 WL 5314595, at*5 (Fed. Cl. Spec. Mstr. Aug. 30, 2013) ("Because it is a broad remedial statute, the Vaccine Act and its provisions are to be construed in a manner that effectuates that underlying spirit and purpose."); Burch v. Sec'y of Health \& Human Servs., No. 99-946V, 2010 WL 1676767, at *9 (Fed. Cl. Spec. Mstr. Apr. 9, 2010) ("[W]ith respect to interpretations of the Vaccine Act, which clearly is a 'remedial' statute, the sovereign immunity canon of 'strict construction' is, in effect, 'offset' by the competing statutory construction principle of 'liberal construction' of remedial statutes ....").

252. See Atchison, Topeka \& Santa Fe R.R. v. Buell, 480 U.S. 557, 562 (1987); Urie v. Thompson, 337 U.S. 163, 181-82, 182 n.20 (1949).

253. This of course is completely antithetical to the principle of narrowly construing waivers of sovereign immunity. See infra Part IV.E. 
fees could be paid even before a judgment is entered. Explaining its rationale in Shaw, the court noted "one of the underlying purposes of the Vaccine Act was to ensure that vaccine injury claimants have readily available a competent bar to prosecute their claims ... . Denying interim fee awards would clearly make it more difficult for claimants to secure competent counsel." 254

Using this paradigm invariably leads to a purposive interpretation instead of a textual, fair-reading interpretation of a statute. ${ }^{255}$ Even if the Federal Circuit's concern about the vaccine bar is true-and the court cites no evidence that the quality of the bar is in jeopardy-that is a prudential (policy) decision that needs to be remedied by Congress, not the judiciary. ${ }^{256}$ When the judiciary makes such decisions, in contravention of the statute's text, it leads to an improper and unconstitutional usurpation of legislative power by the judiciary to make the law "what it should be" in the eyes of the judge. ${ }^{257}$ As eloquently stated by the Supreme Court in Crooks v. Harrelson, "Laws enacted with good intention, when put to the test, frequently, and to the surprise of the lawmaker himself, turn out to be mischievous, absurd, or otherwise objectionable. But in such case the remedy lies with the lawmaking authority, and not with the courts." 258

254. Shaw v. Sec'y of Health \& Human Servs., 609 F.3d 1372, 1375 (Fed. Cir. 2010) (quoting Avera v. Sec'y of Health \& Human Servs., 515 F.3d 1343, 1352 (Fed. Cir. 2008)).

255. A purposive interpretation is unhinged from the text and seeks to achieve what, in the judge's opinion, was the purpose of the law. Invariably, this leads to a judge-by-judge determination of what the law is and thus leads to an unpredictable and inherently discriminatory jurisprudence. SCALIA \& GARNER, supra note 189 , at 16-19; see also William D. POPKIN, A DiCTIONARY OF STATUTORY INTERPRETATION 105, 222 (2007).

256. See, e.g., Jeffrey C. Tuomala, Marbury v. Madison and the Foundation of Law, 4 LIBERTY U. L. REV. 297, 329 (2010) (noting that legislative power is prudential in nature, i.e., forward looking, whereas judicial power is not concerned with achieving some future objective).

257. See, e.g., United States v. Stevens, 559 U.S. 460, 481 (2010) ("We will not rewrite a law to conform it to constitutional requirements, for doing so would constitute a serious invasion of the legislative domain.") (internal quotation and citations omitted); I.C.C. v. Am. Trucking Ass'n, 467 U.S. 354, 379 (1984) (O'Connor, Blackmun, Powell, Stevens, JJ., dissenting) ("[T]his Court is no more authorized than is the Commission to rewrite the law."); Elec. Storage Battery Co. v. Shimadzu, 307 U.S. 5, 14 (1939) ("We cannot thus rewrite the statute."); Friedrich v. U.S. Computer Servs., 974 F.2d 409, 419 (3d Cir. 1992) ("Even if the court does not believe that Congress intended a specific outcome when it drafted a law, the court must give effect to the unambiguously expressed intent of Congress.") (internal quotations omitted); United States v. Shirah, 253 F.2d 798, 800 (4th Cir. 1958) ("[C]ourts are not free to rewrite legislative enactments to give effect to the judges' ideas of policy and fitness or the desirability of symmetry in statutes.").

258. 282 U.S. 55,60 (1930). 


\section{E. Waivers of Sovereign Immunity are to be Strictly Construed}

In addition to the textual canons of interpretation that favor this Article's approach to compensation, "government-structuring" canons of interpretation, such as presumptions against waivers of sovereign immunity, support it as well. Simply put, "a statute does not waive sovereign immunity ... unless that disposition is unequivocally clear." ${ }^{259}$ Although no Supreme Court case has addressed this issue, the Federal Circuit has held that principles of sovereign immunity apply to the VICP. ${ }^{260}$ Recently, in Sebelius $v$. Cloer, ${ }^{261}$ a case regarding untimely filed vaccine injury petitions, the government, in Supreme Court briefs, persuasively advanced the position that sovereign immunity does apply to the VICP, and therefore that ambiguities regarding payment should be construed against any payment of government funds. ${ }^{262}$

In advancing that position, ${ }^{263}$ the government noted that the VICP provides for a monetary claim against the United States by way of suing the Secretary of Health and Human Services in an official capacity. ${ }^{264}$ This suit, moreover, is substantially similar to a general civil action in federal district court in which the United States is represented by the Department of Justice. ${ }^{265}$ The compensation fund is funded by taxes that are levied under the taxing power and are held for the benefit of the United States to be disbursed in a manner consistent with appropriations made by law. ${ }^{266}$ Additionally, the government argued that the vaccine compensation fund is analogous to the Federal Disability Insurance Trust

259. SCALIA \& GARNER, supra note 189 , at 281.

260. See, e.g., Brice v. Sec'y of Health \& Human Servs., 240 F.3d 1367, 1370 (Fed. Cir. 2001), overruled by Cloer v. Sec'y of Health \& Human Servs., 654 F.3d 1322 (Fed. Cir. 2011); Martin ex rel. Martin v. Sec'y of Health \& Human Servs., 62 F.3d 1403, 1405 (Fed. Cir. 1995) ("Because their claim against the United States implicates its sovereign immunity from suit, the alleged jurisdictional grant must be narrowly construed.”); Schumacher v. Sec'y of Health \& Human Servs., 2 F.3d 1128, 1135 n.12 (Fed. Cir. 1993).

261. 133 S.Ct. 1886 (2013).

262. See Brief for Petitioner at 29-32, Sebelius v. Cloer, 133 S.Ct. 1886 (2013) (No. 12-235), 2013 WL 75285.

263. The respondent in Cloer, however, argued that the VICP is more akin to a commercial insurance program and, therefore, principles of sovereign immunity do not apply. Brief for Respondent at 48-50, Sebelius v. Cloer, 133 S.Ct. 1886 (2013) (No. 12-235), 2013 WL 476048.

264. See 42 U.S.C. $§ 300 a a-12(b)(1)$ (2012) ("[T]he Secretary shall be named as the respondent."); 42 U.S.C. § 201(c) (2012) (defining "Secretary" as "the Secretary of Health and Human Services").

265. See Brief for Petitioner at 29, Sebelius v. Cloer, 133 S.Ct. 1886 (2013) (No. 12-236), 2013 WL 75285 .

266. See id. at 30. 
Fund, to which the Supreme Court has already applied principles of sovereign immunity. ${ }^{267}$

In its Cloer decision, the Supreme Court appeared to agree with this proposition at least implicitly, but noted that the principles of waiver apply only if the text is ambiguous. ${ }^{268}$ With respect to the specific timing issues in Cloer, the court held that the text was not ambiguous, ${ }^{269}$ and, therefore, declined to rule definitively on the issue.

Regarding pre-merit-decision interim fees, however, using Saunders (and the Federal Circuit's perceived conflict), there is, arguendo, an ambiguity regarding the treatment of "compensation" in $\S 15$ and $\S 21$. Considering the principle that waivers of sovereign immunity are to be construed narrowly, the timing of paying fees under the Act should be strictly construed - in other words, a presumption in favor of not paying fees before a judgment is entered.

The Federal Circuit and the special masters have abandoned this principle of narrowly construing sovereign immunity waivers in their interim fee jurisprudence. For example, in Avera, the court held that "[t]here is nothing in the Vaccine Act that prohibits the award of interim fees." 270 Even though the fees in Avera were "post-merit" interim fees, the Avera analysis ignores the sovereign immunity issues at play. Sovereign immunity exceptions must be "unequivocally expressed."271 The question, therefore, is not whether the Vaccine Act prohibits the payment of government money, but whether the Act allows or mandates the payment of taxpayer money in a particular situation.

There is nothing in the Vaccine Act that positively and affirmatively allows a payment of attorneys' fees before a merit decision has been made; on the contrary, under $\S 15$ (e) such a determination can be made only if "the judgment of the [Court of Federal Claims] on such a petition does not award compensation." ${ }^{272}$ A judgment requires a decision on the merits. Therefore, these pre-merit-decision interim fees violate both the

267. See Reply Brief for Petitioner at 19, Sebelius v. Cloer, 133 S.Ct. 1886 (2013) (No. 12-236), 2013 WL 860453; see also Bowen v. City of New York, 476 U.S. 467, 479 (1986).

268. Cloer, 133 S.Ct. at 1895.

269. Id.

270. Avera v. Sec'y of Health \& Human Servs., 515 F.3d 1343, 1351 (Fed. Cir. 2008) (emphasis added). This is even more peculiar in light of the Federal Circuit's familiarity with waivers of sovereign immunity.

271. See Blueport Co. v. United States, 533 F3d 1374, 1382-83 (Fed. Cir. 2008) ("However, it is well-established that a waiver of sovereign immunity "cannot be implied but must be unequivocally expressed."” (quoting United States v. King, 395 U.S. 1, 4 (1969))).

272. 42 U.S.C. § 300aa-15(e) (2012) (emphasis added). 
principles of sovereign immunity and the principle of strictly construing waivers thereof.

\section{CONCLUSION}

The current practice of allowing pre-merit-decision interim fees is contrary to law and runs afoul of bedrock canons of legal interpretation. This practice, moreover, is adversely affecting the very people that the Act is designed to protect. Based on flawed statutory construction, attorneys have every incentive to not finish cases, withdraw from representation, leave clients in the middle of the bureaucratic VICP, incur additional costs at the expense of the taxpayer, and clog the dockets of the United States Court of Federal Claims and Federal Circuit. These issues could be easily remedied by adhering to established and sound principles of statutory construction. If interim attorneys' fees are a good policy decision, that decision rests soundly within the province of Congress, not the courts. 